\title{
A Neo-Institutional View of the Transaction Cost Drivers of Construction Supply Chain Risk Management
}

DOI:

10.1108/SCM-09-2019-0350

\section{Document Version}

Accepted author manuscript

Link to publication record in Manchester Research Explorer

\section{Citation for published version (APA):}

Obayi, R., \& Enrahimi, S. N. (2021). A Neo-Institutional View of the Transaction Cost Drivers of Construction Supply Chain Risk Management. Supply Chain Management: An International Journal, 1. [SCM-09-2019-0350]. https://doi.org/10.1108/SCM-09-2019-0350

\section{Published in:}

Supply Chain Management: An International Journal

\section{Citing this paper}

Please note that where the full-text provided on Manchester Research Explorer is the Author Accepted Manuscript or Proof version this may differ from the final Published version. If citing, it is advised that you check and use the publisher's definitive version.

\section{General rights}

Copyright and moral rights for the publications made accessible in the Research Explorer are retained by the authors and/or other copyright owners and it is a condition of accessing publications that users recognise and abide by the legal requirements associated with these rights.

\section{Takedown policy}

If you believe that this document breaches copyright please refer to the University of Manchester's Takedown Procedures [http://man.ac.uk/04Y6Bo] or contact uml.scholarlycommunications@manchester.ac.uk providing relevant details, so we can investigate your claim.

\section{OPEN ACCESS}




\section{Supply Chain Management: an International J}

\section{A Neo-Institutional View of the Transaction Cost Drivers of Construction Supply Chain Risk Management}

\begin{tabular}{|r|l|}
\hline Journal: & Supply Chain Management: an International Journal \\
\hline Manuscript ID & SCM-09-2019-0350.R4 \\
\hline Manuscript Type: & Original Manuscript \\
\hline Keywords: & Transaction Cost Theory, Risk Management, Construction Industry \\
\hline \multicolumn{2}{|c}{} \\
\hline
\end{tabular}

\section{SCHOLARONE Manuscripts}




\section{A Neo-Institutional View of the Transaction Cost Drivers of Construction Supply Chain}

\section{Risk Management}




\section{ABSTRACT}

Purpose: In a departure from the efficiency theory assumptions implicit in most supply chain risk management (SCRM) literature, this study explores the role that external neo-institutional pressures play in shaping the risk management strategies deployed to mitigate transaction cost risks in construction supply chains.

Design/Methodology/Approach: A theory-elaborating case study is used to investigate how regulatory, normative, and mimetic neo-institutional pressures underpin SCRM strategies in stateled and private-led construction supply chains in China.

Findings: The study finds that institutionalized Confucianist networks serve as proxies for regulatory accountability and thereby create a form of dysmorphia in the regulatory, normative, and mimetic drivers of SCRM strategies in state-led and private-led construction supply chains in China.

Originality/Value: The findings reveal that relational costs such as bargaining, transfer, and monitoring costs underpin SCRM in state-led construction supply chains. Behavioral costs associated with search, screening, and enforcement are the core drivers of SCRM in private-led construction supply chains. These differences in transaction cost drivers of SCRM arise from the risk-buffering effect of personalized Guanxi networks, creating variants of institutional pressures on actors' risk analysis, identification, and treatment strategies in China. Considering China's global hegemony in construction and related industries, this study provides valuable insights for practitioners and researchers on the need for a constrained-efficiency view of SCRM in global construction supply chains.

Keywords: Supply Chain Risk Management, Neo-Institutionalism, Transaction Costs. 


\section{INTRODUCTION}

This study explores how external neo-institutional pressures shape the internal transaction cost drivers of Supply Chain Risk Management (SCRM) in China's construction supply chains (CSC) (Halldorsson et al., 2007; Lönngren et al., 2010; Roberts and Greenwood, 1997). A case study of polar-type contractors (state and private) and one Sino-foreign consortium is used to investigate how China's institutional transition from a personalized to a rules-based system affects the SCRM strategies used in mitigating transaction cost risks in CSC (Peng, 2003).

Most extant SCRM studies draw on transaction cost economics (TCE) assumptions to explain supply chain actors' motivations for collaborative risk management (Adhitya et al., 2009; Agrawal and Seshadri, 2000; Chopra and Sodhi, 2004; Manuj and Mentzer, 2008; Riley et al., 2016; Ritchie and Brindley, 2007). The TCE perspective construes SCRM as managing the idiosyncratic risks among collaborating actors with high transaction frequencies and a shared incentive to jointly mitigate transaction uncertainty, behavioral contingencies, and asset-specific risks (Emery and Marques, 2011; Stranieri et al., 2017). In this regard, several studies have demonstrated how such transaction cost considerations determine the scope of risk identification and analyses among supply chain actors (Brown and Potoski, 2003; Blome and Schoenherr, 2011; Gümüş et al., 2012; Kwon et al., 2010; Wever et al., 2012; Hoffmann et al., 2013).

However, supply chain risks could also arise from institutional externalities beyond the internal transactional relations that underpin value creation and impose risks on supply chain actors (Aqlan and Lam, 2015; Hajmohammad and Vachon, 2016). Nevertheless, few studies have explored how such external institutional factors may influence the SCRM strategies that supply chain actors in a given context choose to adopt to mitigate transaction risks (Park et al., 2016; Tummala and 
Schoenherr, 2011). Recent systematic reviews have noted that the disproportionate focus of the SCRM literature on internal operational risks at the expense of external (institutional) disruption risks is a significant drawback to SCRM research (Colicchia and Strozzi, 2012; Fan and Stevenson, 2018). The institutional view is crucial for advancing SCRM research because the risk behaviors and strategies adopted by supply chain actors' are inadvertently linked to the institutional factors that undergird risk information sharing in any given supply chain (Grötsch et al., 2013; Van de Ven et al., 2013). Some studies have suggested that external institutional pressures legitimize the SCRM strategies preferred by supply chain actors (John et al., 2001; Cheng and Chen, 2016; Zsidisin and Ellram, 2003; Zsidisin et al., 2005). To this end, very few (if any) empirical studies have examined the role of coercive, normative, and mimetic neo-institutional pressures in determining supply chain actors' preferred strategies for identifying, analyzing, and treating transaction cost risks (Fan and Stevenson, 2018; Lönngren et al., 2010; Roberts and Greenwood, 1997). Accordingly, this study aims to explore the coercive, normative, and mimetic neoinstitutional pressures that shape the SCRM strategies used to manage transaction cost risks by state-led and private-led CSC in China.

Fan and Stevenson (2018) called for more industry-specific studies to improve our understanding of SCRM beyond the traditional focus on manufacturing settings. Accordingly, CSCs were selected as the context for this study due to distinctive characteristics like public-private alliances, trans-national externalities, temporary configurations, service-based agreements (Buzacott and Peng, 2012; Hartmann and Caerteling, 2010; Kurniawan et al., 2017). Furthermore, the study draws on neo-institutional theory and TCE assumptions in response to calls in the literature for studies to adopt a constrained-efficiency approach in exploring the internal (operational efficiency) and external (institutional) drivers of SCRM (Colicchia and Strozzi, 2012). Thus, this study 
investigates how neo-institutional pressures in China shape the SCRM strategies used to manage different transaction cost risk exposures in CSC. To this end, the following research question is explored:

How do the external neo-institutional pressures constrain the SCRM strategies for managing transaction cost risks facing CSC actors in China?

The structure of the rest of this paper is as follows. The review section evaluates the unique features that make CSCs in China a proper context to study the neo-institutional pressures on SCRM. Next, the literature on SCRM is reviewed to espouse the transaction cost and neo-institutional determinants of SCRM in CSC. The methodology chapter presents the study's theoretical framing, case selection, data collection, and analyses. Finally, the study's findings are presented, and a constrained-efficiency framework of SCRM is discussed to underpin the study's theoretical and practical implications for SCRM in the construction sector.

\section{REVIEW}

\subsection{The Unique Characteristics of Construction Supply Chains (CSC)}

Hatmoko and Scott (2006) define CSC as "a system where clients, contractors, subcontractors, and suppliers work together in a coordinated fashion to utilize information to produce, install, and deliver materials, plants, temporary employment, equipment, labor, and other resources for a construction project." Given the episodic nature of construction projects, CSCs are usually configured as temporary virtual enterprises with several distinctive actors carrying out boundaryspanning operations (Segerstedt and Olofsson, 2010). Unlike manufacturing supply chains, CSCs are characteristically temporary arrangements of multi-national stakeholders with public-private 
governance structures, which increases the tendency for mistrust, power imbalances, and transaction cost risks (Briscoe and Dainty, 2005; Hartmann and Caerteling, 2010).

Since CSCs have finite durations, temporary sites, and episodic relationships, they are more prone to classical agency challenges such as short-termism, opportunism, and high-risk exposure (Behera et al., 2015; Osipova, 2015). In addition to such internal transaction cost risks, CSCs are also prone to other externalities associated with fiscal crises, governance, and policy risks (Aloini et al., 2012; Fearne and Fowler, 2006). Furthermore, CSCs often use Engineering, Procurement and Construction (EPC) contracts to establish 'special purpose vehicles' (SPVs) with short-term stakeholders, high regulatory trade risks, and bespoke supply chain governance structures (Hartmann and Caerteling, 2010; Kurniawan et al., 2017; Wang et al. 2011). Due to the varied range of actors operating in different phases of EPC contracts, CSCs are usually managed in fragmented project silos, from the initiation and planning phases to the actual construction and closure phases (Arantes et al., 2015; Wu et al., 2014). With these unique characteristics, SCRM is critical for ensuring the feasibility and viability of contractual and operational relationships in CSCs (Brinkhoff et al., 2015).

\subsection{Supply Chain Risk Management (SCRM)}

Supply chain risk refers to the occurrence probability and severity of potential hazards arising from micro-level (intra-firm), meso-level (inter-firm networks), and macro-level (inter-industry) interactions among supply chain actors (Farris and Manuj, 2018). It reflects the sum of hazard exposures and the overall likelihood of adverse effects resulting in material losses to key supply chain actors (Colicchia and Strozzi, 2012). In the construction sector, supply chain risks often materialize as endogenous operational disturbances and tactical disruptions or exogenous rupture 
risks and strategic uncertainties from related industries or the external business environment (Bendoly et al., 2014; Fan and Stevenson, 2018). Consequently, construction contractors usually require project guarantees such as vesting certificates and advanced payment bonds to mitigate some supply chain risks (Humphreys et al., 2003). However, such remedies sometimes increase the costs and downside risks of CSC operations (Kettunen and Salo, 2017). With recent developments in digital construction service contracts and third-party logistics, construction productivity has improved significantly over the last two decades (Doran and Giannakis, 2011). Nonetheless, such contractual innovations also inadvertently amplify the tendency for relational risks, project delays, and contractual failures (Chang, 2014).

While early SCRM studies like Kleindorfer and Saad (2005) viewed SCRM as 'planning for the worst and hoping for the best,' contemporary views suggest that SCRM should, ideally encompass pre-contractual and post-contractual uncertainties and a broad spectrum of potential hazards across CSC (Manuj and Mentzer, 2008). SCRM in CSCs, thus, requires joint service agreements and procedures to shield parties from quality defect liabilities, rectification costs, and project failures (Rudolf and Spinler, 2018). Consequently, SCRM in CSCs entails the concerted deployment of risk management strategies by stakeholders to reduce loss probabilities, risk event frequencies, loss speed, and risk event detection time (Manuj and Mentzer, 2008). According to Shen et al. (2006), the six predominant categories of risks that affect global Sino-Foreign construction joint ventures include financial, legal, management, market, policy, and technical risks.

From a review of Flanagan and Norman, (1993) classic risk management framework, 27 pioneering SCRM studies, and the International Standard Organization (ISO 31000) risk framework, De Oliveira et al. (2017) outlined the four critical phases of construction SCRM as risk identification, risk analysis, risk evaluation, and risk treatment. Risk identification connotes 
the use of historical data, experts' opinion, and management judgment to document existing or emerging risks (Bendoly et al., 2014; Fan and Stevenson, 2018). Risk analysis entails the measurement and evaluation of expressed and potential supply chain risks. It includes qualitative approaches (e.g., assumption analysis, brainstorming, interviews, checklists, the Delphi Technique, risk registers, and functional design and process Failure Mode and Effects Analysis (FMEA) or quantitative tools and techniques (e.g., decision trees, sensitivity analysis, and Monte Carlo simulation) (Fan and Stevenson, 2018; Raz and Michael, 2001). Risk treatment refers to the strategies used to manage potential hazards that are flagged-up in the risk assessment phase and includes the four distinct strategies of risk avoidance, risk reduction, risk transfer, and risk retention (Aqlan and Lam, 2015; Hajmohammad and Vachon, 2016; Park et al., 2016).

Despite advances in SCRM literature, the implementation of SCRM in CSC is often impeded by a lack of requisite SCRM experience and inadequate risk information sharing among CSC actors (Chileshe et al., 2016; Gadde and Dubois, 2010; Harner, 2010). The consensus in the literature is that the barriers to SCRM implementation are primarily due to behavioral differences arising from the isomorphic institutional pressures that determine the risk behaviors in stakeholders' respective organizational domains (Chowdhury and Quaddus, 2016; Fischl et al., 2014; Kache and Seuring, 2014; Liu et al. 2010; Zsidisin et al. 2005).

Accordingly, this study addresses two main shortcomings in extant SCRM studies (Chopra and Sodhi, 2004; Manuj and Mentzer, 2008; Tummala and Schoenherr, 2011). First, most SCRM studies emphasize risk on the identification and risk analyses phases of SCRM but provide little guidance on the institutional factors that impact actors' risk treatment behaviors (Colicchia and Strozzi, 2012; Fischl et al., 2014; Kache and Seuring, 2014). Secondly, most studies invoke efficiency-theory assumptions to explain the motivations for collaborative SCRM (Colicchia and 
Strozzi, 2012; Fan and Stevenson, 2018). As such, most SCRM studies focus on the management and mitigation of internal risks associated with transaction uncertainty, behavioral contingencies, and asset-specificity within supply chain hierarchies (Brown and Potoski, 2003; Blome and Schoenherr, 2011; Gümüş et al., 2012; Kwon et al., 2010; Wever et al., 2012; Hoffmann et al., 2013). However, there is a gap in understanding how the external neo-institutional factors that influence the norms and values on risk management within specific institutional contexts affect actors' choice of SCRM strategies (Aqlan and Lam, 2015; Hajmohammad and Vachon, 2016; Park et al., 2016; Tummala and Schoenherr, 2011).

\subsection{Transaction Cost and Neo-Institutional Determinants of SCRM in CSC}

Due to high transaction uncertainties, different contractors in CSCs incur certain transaction costs whenever they sign construction agreements. These costs include the time and money spent in probing the market for reliable partners, negotiating and enforcing contracts, and managing contingencies (Suddaby, 2015; Williamson, 1987; Williamson, 1990). As shown in Table 1, the main categories of transaction costs in CSC include search costs, screening costs, bargaining costs, transfer costs, monitoring/oversight costs, and enforcement/compliance costs (see Emery and Marques, 2011; Stranieri et al., 2017; Zipkin, 2012). However, while transaction costs underpin the identification and analyses of supply chain risks, the risk treatment strategies for mitigating the impact of transaction cost risks depend primarily on external institutional contingencies (Colicchia and Strozzi, 2012).

\section{[Insert Table 1 about here]}

Institutionalism is a multidisciplinary approach to theorizing about the nexus between the economic and socio-political realities that underpin business strategy deployment (DiMaggio and 
Powell, 1983; Suddaby, 2015). The institutional theory focuses on how formal and informal social interactions among actors legitimize the unique institutional structures that define actors' prevalent behaviors (DiMaggio and Powell, 1983). Neo-institutionalism - a contemporary version of the theory- posits that beyond economic considerations, socio-cultural and political pressures from stakeholders, government lobbyists, and supra-national regulators create unique institutional environments, which, in turn, shapes strategy deployment (Williamson, 1987; Williamson, 1990). The theory proposes that institutions are responsible for driving conformity, governance, and legitimacy among actors through coercive (legislative), normative (socio-political and sociocultural norms), and mimetic (peer pressure) mechanisms (DiMaggio and Powell, 1983; Suddaby, 2015). Coercive mechanisms are derived from external entities whose expectations are compelling enough to force actors within an organizational field to behave in particular ways. Normative mechanisms arise from the professional expectations of other actors within similar organizational fields. Mimetic mechanisms drive actors to emulate the practices of others in the same organizational setting because they deem such practices rational and isomorphic. According to DiMaggio and Powell (1983, p. 157), these mechanisms operate against the backdrop of "elite interests," which underpin the behaviors and expectations of institutional actors. As such, the core assumption of neo-institutionalism is that actors do not all pursue optimal management outcomes in a quasi-rational manner. Instead, they are compelled by the rational myths and socially constructed realities of their institutional settings, which confer legitimacy on specific behaviors and strategies in a given domain of activity.

However, Oliver (1992: 563): argued that most "institutional theorists place particular emphasis on legitimation processes," and this creates a high "tendency for institutionalized organizational 
structures and procedures to be taken for granted." Since CSCs comprise several different actors, construction contracts' moral hazards (bounded rationality, market uncertainty, inter-party asset specificity, and opportunism) depend primarily on the institutional mechanisms that shape actors' risk appetite or averseness. Thus, it is important to understand how both the "symbolic" (institutional), "material” (transactional) factors within CSCs interact to shape actors' behaviors and the isomorphic SCRM strategies adopted (McCloskey, 2016; Zuckerman, 1999).

In addition to the institutional pressures that characterize actors' risk behaviors in an organizational field, governments' elite interests also contribute to institutional isomorphism (DiMaggio and Powell, 1983). In this regard, Monticelli et al. (2018) found that firms in volatile or transition economies display a form of institutional dysmorphia by selecting markedly different management strategies from their counterparts in stable and regulated economies. China's expanding hegemony in the global construction sector provides an exciting context to explore the impact of neoinstitutionalism on the SCRM strategies used in global construction projects (Morck et al., 2008; Olson and $\mathrm{Wu}, 2011)$. Over the last decade, China has made substantial asset-specific investments in Engineering Procurement and Construction (EPC) projects like the Belt and Silk Road initiative. This initiative has placed China's construction industry at the forefront of cross-boundary trade and investment in CSCs across Europe, Asia, and Africa (Hurley et al., 2019). Furthermore, China has been making efforts to restructure its excess capacity and infrastructure gaps in the Asia Pacific (presently estimated at $\$ 1.7$ trillion per year) to move its economy from manufacturing-led to service-led (Peel and Mitchell, 2017).

The existing research on market-led institutional transitions suggests that emerging economies like China should (in theory) become more competitive as they progress from informal institutions to more formal (globally interoperable) rule-based ones (Chen and Orr, 2009; Peng and Heath,1996). 
However, Peng (2002) explained that following institutional transitions, there is a time lag for updating management practices due to tensions between external institutional change and internal institutional inertia. In China, the predominant institutional inertia stems from the country's interpersonal approach to dyadic business relationships and risk management known as "guan-xi" (Park and Luo 2001; Peng, 2002). The term Guanxi comprises two distinct characters - "guan" (meaning a gate or a barrier) and "xi" (meaning a tie or connection) (Hwang 1987). In Chinese CSC, Guanxi is the institutionalized approach for interpersonal relationships among actors and affects how SCRM is construed (Tsang, 1998).

Peng (2004 p.1050) argued that western CSC contracts are based on universalistic principles such as quantitative risk assessments and rigorous supplier qualification and selection protocols. However, in China, CSC contracts are based, in part, on concentric circles of Guanxi-personalized networks that extend from core family ties to broader social connections. Consequently, Chinese CSC relationships (whether local or international) are usually non-universalistic and depend implicitly on guaranteed mutual interests and benefits. The resulting institutional pressures on actors in such supply chains tend to be "utilitarian rather than emotional" and are "based [almost] entirely on the exchange of favors" (Park and Luo 2001 p.457). According to Tsang (1998 p.64), informal connections are "essential to gaining approval for or access to just about everything in China." As such, the institutional context compels actors to distinguish between SCRM for "ingroup relationships" among Guanxi actors and SCRM for "out-group relationships" where actors "treat each person as a guest, but guard against them like a thief" (Gabrenya and Hwang, 1996 p. $310)$.

Although China has undergone significant economic and regulatory reforms to become a global player in CSCs, policy and regulatory changes are arguably insufficient to modify the pressures 
exerted by informal institutions (Peng, 2000; Peng and Heath, 1996). Peng (2003) argued that firms cope with institutional inertia by relying on network-based trust and informal agreements to mitigate market-oriented transition economies' transactional uncertainties. However, as marketoriented pressures increase the scale and complexity of transactions, firms begin to depend on formal institutions to counter the inertia imposed by traditional relational structures (Peng, 2002; Peng and Heath, 1996). For instance, the international laws on turnkey and EPC contracts ascribe the liability for procurement risks to contractors, and project owners are responsible for outlining procurement requirements to contactors (Wang and Fang, 2018). However, under the Model Construction Project Contract developed by the State Administration for Industry and Commerce in China, owners cannot designate suppliers for EPC construction contracts (Lu et al., 2015). Instead, specific contractual clauses that cover procurement risks are included in the fixed unit price or lump sum price contracts predominant in China's CSC (Wang and Fang, 2018).

As illustrated in this example, customary institutions remain central to China's SCRM strategies in CSC, despite ongoing regulatory reforms (Peng, 2000; Peng, 2003; Monticelli et al., 2018). Furthermore, to deliver successful construction projects, local, international, and Sino-foreign CSC actors require common regulatory and procedural goals under conditions of uncertainty and task interdependence (Lavikka et al., 2015; Peng, 2000). In this regard, Lavikka et al. (2015) argued that contractual coordination for reducing transaction costs must be augmented with procedural coordination to account for the behavioral, technical, socio-cultural, and socio-political realities of collaborative risk management.

\section{[Insert Table 2 about here]}


Hence, to understand how institutionalized pressures on supply chains influence SCRM strategies, this study attempts to explore the neo-institutional pressures that underpin SCRM strategies in state-led and private-led CSC in China. As summarized in Table 2, four interrelated constructs are explored in this study to understand how neo-institutionalism determines actors' preferred SCRM strategies. The constructs include the main CSC risk categories, transaction costs, neo-institutional pressures, and risk treatment approaches for mitigating transaction cost risks in CSC. These constructs are construed as process-based because they are non-deterministic and context-specific (Mohr, 1982; Van De Ven and Poole, 2005). Thus, by examining how these constructs interact in CSCs, this study would highlight the institutional modalities that shape the SCRM strategies that state-led and private-led CSC actors in China's transitioning economy deploy to cope with transaction cost risk exposures.

\section{METHODOLOGY}

\subsection{Design}

This study adopts a multiple case study and process-based analysis to explore how China's institutional environment shapes the SCRM strategies for transaction cost risk mitigation in CSC (Peng, 2003). The process approach relies on narrative accounts from experts in a given field to understand how stakeholders make decisions and choices about a phenomenon under investigation in a given context (see Van de Ven and Huber, 1990). In contrast to the variance theory approach, which examines causal links among variables, process-based research attempts to document as much as possible, the sequence of events relevant to the processes under investigation (Mohr, 1982). The process-approach was particularly suited to this study because the objective is to understand the temporal order and probabilistic interaction among the transaction cost and neo- 
institutional factors that influence SCRM strategies in the sampled CSCs in China (Van De Ven and Poole, 2005; Mohr, 1982). The study aims to answer the research question: how do the external neo-institutional pressures constrain the SCRM strategies for managing transaction cost risks facing CSC actors in China? Thus, process-based case analysis focuses on providing contextual detail using a few indicative cases (Golden-Biddle and Locke, 2007). In this regard, Langley (1999 p.695) explained that: "ideally, the variety and richness of the incidents described and the linkages between them should convey a high degree of authenticity that cannot be achieved economically with large samples."

\subsection{Case Background}

According to Choi and Wu (2009 p.265), triads of actors are the smallest unit of supply chain analysis of supply chain processes. In CSC, these triads usually comprise state-owned or private lead contractors, medium-scale state or private sub-contractors, and suppliers' consortia. Wynstra et al. (2015 p.13) explained that such service triads consist of "relationships between a buyer, supplier, and the (buying organization's) customer". Thus, to frame the study' unit of analysis as the CSC, two polar types of CSCs were explored:

(a) A state-led CSC with local subsidiaries and suppliers from a Sino-foreign consortium of suppliers.

(b) A private-led CSC with state-owned sub-contractors and a Sino-foreign consortium of suppliers.

To gather the data relevant for both types of CSC, three cases were included in the study. Case A is a Shanghai-based, state-owned, and large-scale construction and engineering corporation, comprising over 20 independent subsidiaries in architectural design, residential building, 
construction and fabrication, engineering installation, real estate, and other related sectors. Case A was established in 2007 with a premium class certificate to act as the main contractor in state-led and international projects. Its subsidiaries operate as sub-contractors on both state and private-led CSC projects. As of 2016, the annual value of completed projects by Case A stood at $\$ 1.7$ billion. The second case is a medium-scale privately owned lead contractor (Case B), founded in 2005 with a class B construction certification to act as sub-contractors for state-owned projects and lead contractors in private class B projects. Case B specializes in Engineering, Procurement, Construction, and Financing projects (EPC and EPCF). As of 2016, Case B's annual value of the completed projects stood at $\$ 630$ million. Case $\mathrm{C}$ is a Chinese industrial consortium with over 1000 international contractors in Engineering, Purchasing, Construction and Finance (PC, EPCF) in a range of sub-sectors like water supply, sewage, and environmental protection, telecommunication, hazardous waste disposal, electrical installation, and construction human resources supply services. Competent authorities like the Ministry of Commerce (China), Ministry of Civil Affairs (China), All-China Federation of Trade Unions, recognize the consortium and the International Chamber of Commerce, and three supplier firms (one respondent each) from Case $\mathrm{C}$ were interviewed.

\subsection{Data Collection}

In the lead-up to the 19th National Congress of the Communist Party of China, the second author attended a series of inaugural 'Belt and Road' conferences held in the UK and China to strengthen value chain connections between China's CSC and Sino-foreign partners. At a One Belt One Road conference organized by Oxford University Faculty of Law in 2017, the research idea was presented to potential respondents. A letter of participation was issued to interested participants from the three case organizations. The purposive sampling of potential informants was based on 
the potential for response intensity (strategic, tactical, and operational responses) and maximum variation considerations for the polar-type case selection (see Table 3) (Gentles et al., 2015).

Following a series of emails, the authors arranged interviews with one informant from the individual cases to discuss the study's scope and objectives. Following a similar conference in London in the same year, both authors organized 30 minutes long in-person informal interviews with the three respondents to refine the interview questions' framing through expert opinion. Through this process, the respondents helped identify other potential informants to provide additional insights on the transaction cost risks and neo-institutional dynamics in China's CSC, bringing the total number of interviewees to nine. The nine respondents included experienced managers with strategic and tactical insights on CSCs in China to facilitate the study's theoretical elaboration (Barratt et al., 2011). The strategic C-suite informants provided insights into the organizational, management, and historical development of SCRM in both state and private-led CSC. On the other hand, the tactical project-level informants provided granular operational and technical details on the SCRM tools and techniques used, the primary transaction cost risks, and the neo-institutional pressures facing CSC in China (Langley, 1999; Barratt et al., 2011). The respondents included three women and six men with an average of 16 years of experience in CSC, and the relevant demographic details are captured in Table 3.

Subsequently, each respondent was interviewed via Skype for one hour, respectively, over three months. Each respondent was asked ten open-ended interview questions (Appendix 1) to gather in-depth process information in three question segments: 
1. The first set of questions explored respondents' expert opinions on the SCRM tools and techniques (quantitative and qualitative) used for transaction cost risk identification and analysis in CSC in China (De Oliveira et al., 2017).

2. The second set of questions investigated the key transaction cost risks in state and privateled CSC (search, screening, bargaining, transfer, monitoring, and enforcement costs) (Emery and Marques, 2011; Stranieri et al., 2017).

3. The third set of questions explored the neo-institutional drivers of SCRM risk treatment strategies used in state-led and private-led CSC (avoidance, reduction, transfer, and retention) (Liu et al., 2010).

In the three rounds of questioning, the respondents from Case 3 (the Sino-foreign consortium of suppliers) were asked to reflect on their experiences in both state-led and private-led CSC. In addition to the semi-structured interviews, the authors held informal conversations with the respondents before and after the scheduled interviews to gather other relevant process-based data relevant to the analysis (Van de Ven and Huber, 1990).

\section{[Insert Table 3 about here]}

Finally, to counter the low precision of qualitative data and strengthen the credibility of the study's findings, a multi-method triangulation of case data, literature, and archival data was used. The archival data used included firm-level risk management policies, the International Construction Risk Assessment Model (ICRAM-1), the ISO 31000:2009 risk management principles, and reviews on China legislation and policies on construction risk management (Chan and Suen, 2005; Hastak and Shaked, 2000; Sousa et al., 2012; Yow Thim and Zonggui, 2004).

\section{ANALYSIS}




\subsection{Data Analysis Approach}

Although most respondents were proficient in English, a mandarin translator was used to translate the interview responses given in mandarin (see Appendix $1 \mathrm{~b}$ for excerpts). Case-based memos from the interviews were used to capture the interviewers' impressions on the respondents' experiential narratives. Conceptual notes were used to capture the development of the initial and focused codes to facilitate vibrant theoretical abstraction (Barratt et al., 2011; Langley, 1999).

\subsection{Data Coding}

The transcribed interviews were coded independently by the authors using a coding protocol on excel to align the data to the literature's descriptive codes. The abductive approach to qualitative analysis was used to link deductive codes from the literature to the respondents' conversational language from the interviews to arrive at analytical themes (Langley, 1999). This allowed the authors to capture "the best comprehensive, coherent, and simplest model for linking diverse and unrelated facts in a useful and pragmatic way" (Morse 1994 p.25). The authors began by developing open codes to rationalize the data into discrete meaningful units of first-order descriptive codes that linked the respondents' thoughts, ideas, and expressions to the research concepts explored (Langley, 1999). The germane descriptive codes were then clustered using phrasal descriptors to structure the data into abstract categories based on the properties (or common features) and dimensions (locus of each property on a continuum) of the descriptive codes (Strauss and Corbin, 1998 p.101). Finally, a constant comparative approach was used to relate "each incident in the data with other incidents appearing to belong to the same category, exploring their similarities and differences" (Spiggle 1994 p.493). 
To arrive at analytical codes, the descriptive codes were grouped into interpretive clusters by both authors with the aid of visual maps and spreadsheets. At this phase, the authors brainstormed to refine the analytical codes drawing on their supply chain management and EPC contract law expertise, respectively. The analytical codes were further refined with valuable inputs from the interview informants, academic colleagues, and the manuscript review process. The clustering resulted in six distinct neo-institutional drivers of SCRM in state-led and private-led CSC:

1. Means-Based Regulatory Pressures on Risk Analysis in State-Led CSC

2. Performance-Based Regulatory Pressures on Risk Analysis in Private-Led CSC

3. Descriptive Normative Pressures on Risk Identification in State-Led CSC

4. Collective Normative Pressures on Risk Identification in Private CSC

5. Adaptive Mimetic Pressures on Risk Treatment in State-Led CSC

6. Replicative Mimetic Pressures on Risk Treatment in -Led CSC

Figure 1 presents a concise sample of the clustering of descriptive codes that resulted in the six analytical codes presented in the findings.

\section{[Insert Figure 1 about here]}

\section{FINDINGS}

\subsection{Means-Based Regulatory Pressures on Risk Analysis in State-Led CSC}

Respondents from Case A acknowledged that the regulatory provisions of the Government Procurement Law (GPL), tender law, and local government procurement laws are used to inform EPC contract risk analysis in state-led CSC in China. These legislations' technicalities comply with the risk management provisions of ISO3000 and The International Construction Risk Assessment Mode (ICRAM-1) (Hastak and Shaked, 2000). According to respondents B, such regulatory provisions empower lead contractors to oversee all the sub-contracts within the CSC, thus, serving as a SCRM framework for contractual risks. They explained that: 
"The legislation promotes a SCRM culture for contractual risks, which enables leadcontractors to improve project planning, work allocation, and relationship management for the interdependent stages of EPC contracts"

However, the findings revealed that such state-sanctioned lead contractors enforce the regulation of contract risk analysis for force majeure, material delays, variations, and other negotiated contract provisions based on the degree of embeddedness of sub-contractors' and suppliers' in existing guanxi construction networks. The respondents from case A further explained that qualitative contract risk analysis is preferred in state-led CSC because lead contractors' have the "means" to use their institutional powers of persuasion to gain access to relevant risk information on local subcontractors and suppliers at the bid inquiry phase. Respondent A explained that such qualitative analyses often lead to the arbitrary and sometimes unfair apportioning of contract risks and claim indemnities among state-sanctioned lead contractors, sub-contractors, and suppliers.

Respondent B explained that the main shortcomings of qualitative contract risk analysis by statesanctioned actors include "poor procedural coordination," "lack of standardized data on contractors' performance," and a "poor risk information-sharing culture" among state actors. These shortcomings affect state-led CSC's capacity to acquire sufficient qualitative risk information on sub-contractors and suppliers throughout the lifecycle of a construction project (Peng, 2002). According to respondent A:

"We must strengthen our collaborative relationships with suppliers and subcontractors by updating and appraising our soft communication and risk information-sharing capabilities. This helps us identify and manage potential risks; otherwise, we could easily lose control of projects without an established system for risk-sharing with partners."

Respondents $\mathrm{C}$ added that state-led contractors rely on this "soft networking approach" to assess the degree of embeddedness of subcontractors in government networks as a means for appraising their risk profiles. However, they noted that since contractual risks are quite subjective, state-led 
CSCs often struggle to develop the right "risk analysis scope for SCRM." Respondent A added that:

"We do not routinely use complicated risk management tools to rationalize the day-to-day risks presented by suppliers and sub-contractors because such techniques make the management of our relationships and cumbersome construction schedules more complex."

Respondents C explained that although state-led CSCs have quantitative risk analysis expertise, lead-contractors use a command-and-control style to institutionalize the adoption of a qualitative approach to contract risk analysis based on actors' embeddedness in social networks. According to respondent $\mathrm{H}$ (a building materials supplier), the means-based regulatory pressures that have institutionalized qualitative risk analysis in state-led CSC stem from the China Contract Law of 1999. The legislation authorizes only competent departments of the State Council to determine the mandatory risk categories for state-led EPC contracts. Since state actors are empowered with the regulatory means to determine the EPC risk categories qualitatively, the risk analysis phase of SCRM in state-led CSC is less transparent because several state-sanctioned authorities are involved. In this regard, respondent A explained that:

"The primary Ministry of Finance oversees public procurement while other ministerial authorities like the National Development and Reform Commission, the Ministry of Science and Technology, the Ministry of Commerce, the Ministry of Communications, and the Ministry of Housing and Urban-Rural Development regulate other aspects of construction work. Local authorities also supervise procurement and construction activities, and sometimes send conflicting messages, so lead contractors must be flexible in determining EPC contract risk categories, which tend to be different with each project depending on which authority is involved."

Respondent $\mathrm{G}$ explained that China's procurement legislation has allowed for competitive bidding and tendering since 1984 to level the playing field for private and Sino-foreign contractors. However, state-led CSCs still operate using private tenders, tenders by invitation, and performance or surety bonds backed by government insurers to guarantee satisfactory project completion. In 
state-led CSC, contractors use their access to relevant government authorities to source risk information on the past contract performances to develop qualitative risk profiles for statesanctioned sub-contractors and suppliers. Such risk information databases also reflect contractors' embeddedness in relevant Guanxi networks and provide the qualitative data used for private tender selection and the mitigating of potential default risks. However, respondent B explained that:

"There is no central information-sharing system or protocol; rather, we have to collate bespoke risk information on state-sanctioned contractors from several independent ministerial authorities. This means that lead contractors in public projects enforce certain aspects of the legislation that facilitate qualitative risk analysis for private bidding to ensure that projects encounter minimal shocks."

Similarly, concerning risk analysis for technology risks, respondent I (equipment supplier) explained that:

"Our national government aims to support Chinese innovation to reduce dependence on foreign technology in state-led construction projects. The National Development and Reform Commission, the Ministry of Finance, and the Ministry of Science and Technology have policy mechanisms for analyzing and estimating technology transfer and innovation risks. While such policy reforms aim to change our system from a closed to a transparent one, decisions about technology risks in state-led projects rely on established relational agreements between government agencies and state-sanctioned contractors. The emerging reforms apply mostly to private-led CSC projects."

Respondent I, an equipment supplier to state and private contractors in China, explained that supply contract risks are analyzed using standardized quantitative and qualitative risk assessment templates in rules-based jurisdictions. For instance, in jurisdictions like the UK, they explained that EPC contractors use standard templates to assess all potential risks in main projects, design and build, and minor works contracts. In other jurisdictions like the US, standard form contracts are uncommon due to differences in state contract legislation, so contractors use standard risk analysis templates by the American Institute of Architects and the American Society of Civil Engineers for commercial projects. In contrast to rules-based jurisdictions, Respondent G (an EPC contractor) explained that the institutionalized mechanism for multi-party risk analysis in state-led 
CSC in China is qualitative brainstorming sessions organized and supervised by governmentappointed third parties. Respondent B explained that quantitative risk analysis is considered "inflexible" in state-led CSC to account for relational ties, potential data sharing, and propriety issues that often arise among state authorities and private contractors, sub-contractors, and suppliers.

\subsection{Performance-Based Regulatory Pressures on Risk Analysis in Private-Led CSC}

The three respondents from case B indicated that, similar to state-led CSC, qualitative techniques and tools were also the primary approaches for analyzing and assessing multi-party contract risks in private-led CSC. However, contrary to the means-based regulatory motivations in state-led $\mathrm{CSC}$, respondents from Case B noted that performance-based regulatory pressures underpin the qualitative risk assessment and analysis phase of SCRM in private-led CSC. In this regard, targetcost contracts are used to ascribe risks, liabilities, and claim procedures to parties based on government-sanctioned risk profiles and the degree of embeddedness in existing Guanxi networks.

Respondents from Case B explained that lead contractors in private-led CSC use qualitative risk analysis to strengthen relational ties with the right network of state and Sino-foreign partners, mitigate potential risks, and attract new investments. Other reasons cited for preferring qualitative over quantitative risk assessment in private-led CSC included "supporting supplier-selection decision processes," "improving budget management," and "ensuring value chain continuity." Respondents D said:

\footnotetext{
"We need the right access to qualitative insights about our suppliers and sub-contractors from different government departments to support our day-to-day decisions and smoothen our interactions with government clients."
} 
According to Respondent $\mathrm{D}$, the performance-based regulatory pressures to use target-cost contracts sometimes presents challenges in contract coordination and risk information sharing between state and private actors in private-led CSC. Other cited challenges with using qualitative risk information to apportion risks in private-led CSC included the "potential to be locked-in with the wrong CSC partners" and the potential for "cross-functional goal misalignment among state and private contractors" in private-led CSC. According to Respondents E:

"The risk profiles used for supplier selection decisions are based on contractors' risk standing with the state. However, day-to-day operational or functional default or failure risks of such contractors are difficult to capture comprehensively through subjective risk assessments of contractors' relational performance by the state authorities. When making time-sensitive selection decisions, it can be challenging to gather relevant information on contractors' performance from multiple state authorities."

In this regard, Respondent $\mathrm{F}$ added that:

"Short-term risks on construction sites can have long-term effects on collaborating contractors. However, the onsite risk and performance assessments used to inform contractors' risk ratings are carried out by career government employees with minimal training or awareness of transparent risk analysis protocols."

To manage these challenges, respondents from Case B noted that they rely heavily on target cost contracts (TCC) as a risk-sharing mechanism to mitigate potential performance shortfalls by state contractors in private-led CSC. In TCC, payments to sub-contractors and suppliers are based on contractors' actual cost and pre-set (pre-contractual) incentives to motivate the alignment of actual time, cost, and delivery performance to stipulated contact targets. As with other industries in China, the construction industry is run on Confucianist social philosophies, which define hierarchical business and societal relationships based on trust, mutual obligation, and network ties instead of codified laws. Consequently, respondent E noted that performance-based qualitative risk assessment through TCC helps private contractors to minimize failure risks with Sino-foreign suppliers while encouraging tenders and relational ties with Guanxi-networked suppliers. 
According to respondent D, performance-based agreements are useful in private-led CSC because, under China Contract Law, fixed-price lump-sum contracts for state construction do not stipulate a cap on sub-contractors and suppliers' liability. Thus, TCC based on qualitative risk analysis of suppliers' risk profiles in Guanxi networks facilitate SCRM in private-led CSC. Respondent G explained that private contractors often resort to lump-sum contracts with exculpatory clauses to minimize failure risks. Although private-led contractors also use the qualitative ranking of partners' Guanxi network embeddedness, such performance-based mechanisms are necessary because there are no state bonds and performance sureties for most private EPC contracts.

According to respondent E, the performance-based regulatory pressures that drive target-cost contracting in private-led CSC could present overrun risks associated with material shortages, budgeting, quotation mismatches, and financial market uncertainties. Moreover, the respondents stressed the importance of personal interviews and informal risk information sourcing in privateled CSC to boost contractors' institutional legitimacy by selecting institutional suppliers and Sinocontractors from personalized networks of influence.

\subsection{Descriptive Normative Pressures on Risk Identification in State-Led CSC}

In line with ICRAM-1 and the provisions of ISO 31000:2009 risk assessment framework, findings showed that the risk identification phase of SCRM entails mapping all pre-and post-contract transaction costs that present potential default or failure risks. All respondents from Case A acknowledged that risk identification in state-led CSC follows a robust set of industry norms regarding the most significant transaction costs associated with multi-party construction contracts. However, the findings revealed that the differences in the predominant contracting approaches used in state and private-led CSC give rise to distinctions in the normative pressures that shape transaction cost risk identification. 
Due to the long-term planning horizon of construction contracts, all respondents from Case A noted that the risk analysis and risk identification phases of SCRM run iteratively throughout the lifecycle of CSC. While the risk analysis phase aims to assess the impact and distribution of risks among CSC actors, risk identification aims to isolate the transaction costs across the contract lifecycle that could materialize as risks to contract performance.

Consequently, the regulatory mechanisms that shape risk analysis in state-led CSC establish certain norms for risk identification. According to Respondent B, bargaining, transfer, and monitoring costs are perceived as primary contract failure drivers in state-led CSC. They added that bargaining costs materialize in state-led CSC due to state and private actors' conflicting objectives and uncertainties regarding the terms, rights, and obligations of government-backed actors (contractor, clients, financiers, and other stakeholders). According to respondent A:

"We often have to invest considerable resources into minimizing our bargaining costs with potential partners. In most projects involving government clients, bargaining costs significantly affect the quoted contract price, and minor price misquotes can materialize as high costs in the long-run."

Since parties to state-led CSC are selected based on network ties, bargaining costs can be relatively high and could result in relational risks since contractual negotiations and renegotiations are ongoing throughout CSC's contract lifecycle. Respondent C explained that:

"In many cases, we can almost accurately determine our material and overhead costs, but we find that the success or failure of projects-especially those involving government clients (which form the majority of our business) depends entirely on our ability to minimize ongoing bargaining and bidding costs."

In the same regard, Respondent B noted that transfer costs constitute another significant transaction cost in state-run CSC because multiple state-backed actors in EPC contracts carry out risk analysis independently and transfer the associated costs to defaulting parties. Consequently, 
the identification of different bargaining and transfer costs in state-led CSC is driven by Descriptive Normative Pressures, which arise from actors' assumptions about ongoing bargaining and transfer costs that could materialize as default or failure risks. Explaining the importance of transfer and monitoring costs to government-led contractors, respondent A asserted that:

"Many of our foreign sub-contractors see our national qualification system as biased in favor of local contractors. Their main criticism is the bidding requirement that requires that all qualification references be obtained from China alone. Also, many foreign subcontractors with whom we work are unfamiliar with the Chinese legal system, so this can generate unpredictable transfer and monitoring costs and lengthen the contracting process compared to other countries."

Respondent G noted that descriptive norms compel state-led CSC to focus on ongoing bargaining and transfer costs as the core sources of risks in state-led CSC due to available government sureties and bonds against material and performance failures. However, such state-led CSC remains prone to other pre-contractual behavioral risks that affect contract performance, such as environmental impact, feasibility, design, and tender certification risks. Respondent $\mathrm{H}$ further explained that the government's focus on promoting local contractors further amplifies the normative perception among state contractors that monitoring costs pose significant risks to CSC, particularly in CSC involving Sino-foreign sub-contractors (Peng, 2002). Regarding monitoring costs, respondent B added that:

"The system for licensing of professionals, particularly those in construction design is quite tedious, and since only firms licensed in China can officially validate construction plans, it raises the monitoring costs for engaging in syndicated projects with global partners."

\subsection{Collective Normative Pressures on Risk Identification in Private CSC}

Findings showed that in private-led CSC, Collective Normative Pressures underpin the identification of transaction cost risks. Regarding collective norms, Respondent E explained that: 
"In 2011, the government changed some of the existing government procurement rules to allow foreign firms to access the local market. However, in our experience, it is not as straightforward as following the regulations because new rules constantly emerge, so we stay in tune with the norms. For instance, along with the open policy, the ministry put out another set of regulations that make it impossible to exclude SMEs and local suppliers from projects involving government procurement activities in some jurisdictions."

Collective norms are established based on contractors' assessment of the actual risky behaviors that materialize as risks to CSC parties. According to the respondents from Case B and Case C, search, screening, and enforcement costs were regarded as the most prominent transaction costs leading to project failure, delay, or breach-related risks in private-led CSC in China (Williamson, 1990). Search and screening costs correlate to the cost of private contractors' information asymmetry about the actual risk profile of state-owned or state-backed Sino-foreign contractors and can be considered as behavioral risks. Regarding the impact of search and screening costs, responded D explained that:

"The new competitive tendering and bidding regulations are not widely adopted yet, nor are they enforced, so some firms can get around the new tendering and bidding regulations, which is a significant concern."

Likewise, respondent $\mathrm{E}$ added that:

"Some of the regulations are still rather obscure, and some procedures around purchasing policies are not published. This sometimes results in costly delays without a robust SCRM strategy in place for finding the right partners and screening them to ensure that future avoidable challenges do not emerge."

While search and screening costs are pre-contractual transaction costs, enforcement costs materialize in construction projects' post-contractual phases. To highlight the importance of enforcement costs, respondent $F$ pointed out that:

"in most cases, certified designers do not (are not permitted to) specify product names in their designs, so some sub-contractors sometimes substitute suppliers during the project without vetting by the designer or owner, and this causes delays and additional expenses." 
On the other hand, contract enforcement costs arise from private contractors' bounded rationality on the impact of potential partners' embeddedness in Guanxi networks on contractors' ability to enforce compliance. In this regard, respondent $\mathrm{F}$ noted:

"In my opinion, for most private contractors, their position and influence within key personalized networks within the industry at state or local jurisdiction levels is just as crucial for mitigating transaction costs as regulations."

According to respondent $\mathrm{H}$, it is difficult for private contractors to access all relevant risk information on network-embedded suppliers and contractors, which increases the tendency to accrue non-compliance costs in bilateral or multi-party agreements. In this regard, Respondent D explained that:

"The quality of project management greatly impacts construction project quality, productivity, and the potential cost of reworks. When there are uncertainties about contract enforceability, project management efficiency declines because contractors' behavior is a better measure of project risks and long-term viability than resources."

All the respondents from Case $\mathrm{C}$ further emphasized that industry, national, and jurisdictionspecific personalized social networks are the institutional drivers of collective normative pressures in private-led CSC (Peng, 2003). In this regard, respondent G explained that:

"It takes a certain level of socialized connections within the industry and the system for any local contractors, suppliers, or subcontractors to develop their intellectual property in China, possess a registered trademark, or have the right licenses to use certain intellectual property in China. Some foreign firms have attained this level of embeddedness, while some important local ones have not."

\subsection{Adaptive Mimetic Pressures on Risk Treatment in State-Led CSC}

The existing research on risk treatment shows that treatment strategies are often copied and shared by players within a given industry as a procedural means to ascribing collective legitimacy to actors. Based on the interviews, two distinct forms of mimetic mechanisms were identified as the main drivers of the predominant risk treatment approaches used in state-led or private-led. The 
respondents from Case A were all familiar with risk avoidance, risk reduction, risk transfer, and risk retention strategies for risk treatment in $\mathrm{CSC}$. However, they noted that risk treatment strategies are applied in state-led CSC in line with the critical transaction costs (bargaining or transfer costs) that materialize as contract default or failure risks. In this sense, the findings showed that state-led CSCs are compelled by Adaptive Mimetic Pressures to determine the most appropriate treatment strategy to mitigate the impact of specific bargaining or transfer related risks while preserving actors' relational embeddedness in personalized networks.

'Risk transfer' was cited by all respondents from case A as the preferred approach to risk treatment in cases where it is contractually possible to transfer or apportion risks to subcontractors in line with existing state-led insurance policies. "Contractors all risks insurance" and "third party liability" contracts were cited by respondent $G$ as the two mandatory insurance policies for all contractors under the strict supervision of government regulatory authorities. Furthermore, respondents from Case A considered 'risk avoidance' as a last resort for risk treatment. According to Respondent A, the decision to avoid risks even after a client's risk profile has been assessed as being "poor" may frustrate future project allocations and result in the loss of future business opportunities. However, according to respondents from Case C, risk reduction is the preferred strategy of government contractors to mitigate supplier failure, quality, or default risks at the initial stages of a project. When material contract breaches occur, contract performance is guaranteed through government-endorsed backup suppliers and risk profile penalties for defaulting subcontractors or suppliers.

\subsection{Replicative Mimetic Pressures on Risk Treatment in Private CSC}


In contrast, privately led CSCs rely on Replicative Mimetic Pressure for risk treatment by copying the practical treatment approaches deployed or dictated by state-owned contractors and regulators. In this regard, all respondents from case B indicated they were familiar with the four risk treatment mechanisms based on past projects. However, they noted that different risk treatment strategies are suited to different risk profiles and different stages of construction projects. Respondents D explained that from a strategic viewpoint, risk avoidance by commercial contractors is considered as an added expense (legal search costs and the potential to miss a viable investment opportunity), particularly where it is difficult to establish the nature of risk to be avoided. Respondent E added that in many cases, private construction firms are sometimes locked-into high-risk projects with government actors, especially where off-site production requires significant upfront costs to set up EPC operations. The respondents from case B further explained that pursuing a risk transfer strategy besides the ones dictated by state-owned contractors or government agencies could result in severe relational issues and loss of investment opportunities (Olson and $\mathrm{Wu}, 2011$ ). All respondents from Case $\mathrm{C}$ explained that in private construction projects, the predominant state actors endorse as the most viable risk treatment strategy for each phase of EPC construction projects.

\section{DISCUSSION}

\subsection{The Impact of Regulatory Pressures on CSC Risk Analysis}

The findings show that neo-institutional regulatory pressures drive the risk analysis and assessment phase of SCRM in private and state-run CSC beyond economic considerations. However, two forms of regulatory pressures were central to shaping the risk assessment and analysis strategies that undergird state-led and private-led CSC. In state-led projects, Means-Based Regulatory 
Mechanisms drive qualitative risk assessments, which form the basis of the government-backed performance sureties for fixed-price lump-sum contracts with sino-foreign and local suppliers. While the means-based risk assessment phase of SCRM is not very transparent in state-led CSC, the government's risk profiling is based on contractors' degree of embeddedness in statesanctioned, personalized Guanxi networks. By contrast, the risk analysis phase of SCRM in privately led CSC is driven by Performance-Based Regulatory Pressures, which shape the targetcost contracts used to manage contractual shortfalls, liability allocation issues, and breach claim procedures. Without the state-backed sureties of government-funded projects, privately led CSC in China use qualitative risk information on contractors' degree of embeddedness in personalized Guanxi networks to develop pre-set incentives and penalty clauses for target-cost contracts. Overall, beyond economic considerations, regulatory neo-institutional pressures shape the risk analysis phase of SCRM. However, access to risk information on local and Sino-foreign contractors' embeddedness in personalized Guanxi networks in China creates polarity in the contracting mechanisms for state-led and private CSC through means-based (lump-sum contracts) and performance-based (target-cost contracts) respectively. Considering the role of institutions in shaping CSC risk analysis beyond economic transaction cost considerations, the first proposition on the neo-institutional theory constrained view of risk analysis in SCRM is:

\section{Proposition 1:}

Coercive neo-institutional pressures underpin the risk assessment phase of SCRM in CSC. However, the polarity between means-based regulations and performance-based regulations shape the contracting approach deployed.

\subsection{The Impact of Normative Pressures on CSC Risk Identification}


State and private-led CSC projects are prone to different transaction costs and risk exposures due to differences in contracting structures and the regulatory pressures that shape contract risk analysis. Consequently, the risk identification phase of SCRM in CSC entails the subjective and procedural mapping of potential transaction costs associated with contractors operating at different phases of construction lifecycles. The findings showed that the risk identification phase of SCRM in China's CSC is primarily driven by the socio-political and socio-cultural normative pressures on actors to generate and share risk information. However, these normative pressures have a polarizing effect on the nature and modality of risk information sharing. In state-led projects, Descriptive Normative Pressures drive the risk identification phase of SCRM as actors focus on isolating and mitigating transaction costs that influence the collective perception of suppliers' and contractors' risk profiles within state-sanctioned personalized networks. Descriptive norms focus on identifying ongoing transaction costs that could impose pre-contracting/bidding related risks using network-based and state-sanctioned perceptual information. Descriptive perceptual norms aim to preserve the viability of Guanxi-driven risk avoidance and risk reduction mechanisms enshrined in government sureties and performance guarantees. As such, descriptive norms are mainly socio-political and not strictly economic. They are derived from actors' social embeddedness and political connections to influence the weighting of contractors' post-contractual risk profiles based on perceived or potential contract bargaining, transfer, and monitoring costs.

By contrast, the risk identification phase of SCRM in private CSC with local and Sino-foreign actors is shaped by Collective Normative Pressures. The norms about actors' actual performance shape CSC parties' focal behaviors and contracting schemes. In such CSC, the normative behaviors that drive risk identification aim to source risk information to reduce pre-contracting transaction costs associated with searching and screening contractors and enforcing clauses in target-cost 
contracts. Private contractors must select suppliers under conditions of information asymmetries and bounded rationality concerning the degree of actors' embeddedness in personalized networks. As such, the collective norms for identifying search, screening, and enforcement costs are largely socio-cultural and relate to actors social embeddedness in personalized networks and the cultural proximity (particularly for Sino-foreign actors) to the business culture in China. Based on the preceding arguments, the second proposition on the neo-institutional theory constrained view of risk identification in SCRM is:

\section{Proposition 2:}

Normative neo-institutional pressures underpin the risk identification phase of SCRM in CSC. However, actors' degree of socio-political and socio-cultural embeddedness creates a polarity between descriptive norms and collective norms for risk information sharing in transitioning economies.

\subsection{The Impact of Mimetic Pressures on CSC Risk Treatment}

As explained, regulatory and normative pressures in state-led and private CSC with local and Sinoforeign contractors determine the contracting liability of actors, the type of risk information shared, and actors' risk profiles within personalized networks. Consequently, CSC actors' risk treatment strategies to mitigate the impact of materialized risks are shaped by behavioral mimetic neoinstitutional pressures to adopt state-sanctioned treatment strategies to enable actors to participate in future CSC projects. In state-led CSC with local and Sino-foreign partners, Adaptive Mimetic Mechanisms determine whether material risks are transferred to contractors in line with government-backed contractors' all risks insurance and third-party liability policies. However, depending on actors' embeddedness in the sectors' Guanxi networks, potential hazards associated 
with supplier failure, quality, or default risks could be subject to risk reduction treatment. Risk reduction is often instituted through government indemnified performance guarantees, which ascribe contractual penalties and procedural reviews of defaulting parties' risk profiles alongside alternative sourcing strategies to ensure contract performance. By contrast, private CSCs subscribe to Replicative Mimetic Pressures, which compel them to adopt the risk treatment option deployed or dictated by state regulators depending on the normative risk profiles and embeddedness of defaulting parties in the relevant Guanxi personalized networks. Risk avoidance by commercial contractors operating in regulated institutional settings could affect their perceived risk profiles in personalized networks and reduce their relational capacity to attract future investment opportunities. Based on these findings, the third proposition on the neo-institutional theory constrained view of risk treatment in SCRM is:

\section{Proposition 3:}

Mimetic neo-institutional pressures underpin the risk treatment phase of SCRM in CSC. However, embeddedness in personalized networks creates polarity in the choice to adapt or replicate risk treatment strategies.

\subsection{Towards a Constrained-Efficiency view of SCRM implementation in China's Construction Industry}

Williamson (1987: 176) argued that in practice, "few economists would insist on an unrelieved efficiency theory of economic organization" and argued that transaction costs must be matched with cognitive and institutional constraints to understand the design and deployment of strategies like SCRM. Figure 2 captures a framework for the neo-institutional drivers of SCRM in state- 
owned and private construction firms and highlights the fluid dynamics of variants of regulatory, normative, and mimetic pressures that shape SCRM in CSC (Peng, 2002).

\section{[Insert Figure 2 about here]}

As shown, the neo-institutional pressures that shape SCRM in CSCs are dynamic. Regulatory pressures shape the practical risk analysis approach through means-based and performance-based contracts. These regulatory realities are different for state-owned and private firms and, in turn, shape the evolution of norms around transaction cost risk identification and the focus of SCRM strategies. In this sense, formal institutions serve as proxies for regulatory accountability regarding transaction cost risks. Whereas personalized networks create descriptive behavioral norms in public entities, the need for self-regulation of CSC risks creates collective behavioral norms in private CSC. Therefore, state-led and private-led CSCs succumb to different mimetic mechanisms for risk treatment driven (in state-led CSC) or imposed (in private-led CSC) by embedded institutionalized risk treatment practices dictated by Confucianist personalized networks. Specifically, Adaptive mimetic pressures drive state-led CSC to focus on relational transaction costs like bargaining, transfer, and monitoring costs.

In contrast, replicative mimesis drives private CSC to focus on behavioral transaction costs such as search, screening, and enforcement costs (Peng, 2003). The dynamics captured in Figure 2 depict two distinct concentric cycles of neo-institutional drivers of SCRM, which somewhat explains some of the dysmorphia observed in transitioning economies' institutions, despite regulatory reforms. Since SCRM exists in separate institutional cycles for state and private CSC, syndicated public-private Sino-foreign CSCs must ensure to plan their SCRM in line with the predominant institutional framework at play to avoid unforeseen transaction cost risks. The 
findings further show that personalized networks in China's CSC dictate, to a large extent, the regulatory, normative, and mimetic pressures that drive SCRM in both state and private CSC.

In addition to the cost minimization role of informal institutions in transitioning economies, the findings show that embedded networks significantly influence industry standards for risk identification, analysis, and treatment via socio-political, socio-economic, and behavioral mechanisms in CSC. The findings further buttress extant theoretical arguments on the interactions between contractual and procedural coordination in CSC (Lavikka et al., 2015). In this regard, regulatory pressures underpin contractual coordination for transaction cost risk analysis and the legal distribution of risks, rights, and incentives based on institutional embeddedness. On the other hand, procedural coordination is exerted through normative and mimetic mechanisms for coordinating the risk identification and risk treatment phases of SCRM in CSC after the contracts are signed.

This study's underlying paradox is that Guanxi or personalized networks in the Chinese construction industry serve as an institutional mechanism for mitigating risks and transaction costs. This finding holds implications for both theory and practice, particularly concerning risk treatment, which is seldom covered in most SCRM studies. By combining efficiency theory considerations of transaction costs for operational and neo-institutionalism for systemic risks in CSC, this study highlights the role of multi-stakeholder participation in both the contractual and procedural coordination that pertain to SCRM in CSC. In this way, the study contributes to the practice of SCRM by highlighting the role of neo-institutionalism in shaping stakeholder value in international construction projects. In this regard, the study sheds light on the role of personalized networks in shaping SCRM practices for companies engaged in Sino-foreign contracts with China. It sheds light on the role of socio-political and socio-cultural embeddedness on risk information 
sharing for CSC risk identification and risk analysis and emphasizes the importance of understanding how institutionalized behavioral norms and adaptations determine stakeholders' risk information sharing for SCRM.

\section{CONCLUSION}

Institutionalism provides a multidisciplinary lens for theorizing about the interactions between the economic and socio-political realities that shape strategy deployment. As exemplified in the polar cases of CSCs in China, regulatory, normative (socio-political and socio-cultural), and mimetic (behavioral) pressures from stakeholders, government lobbyists, and regulators establish a unique institutional environment for SCRM strategy deployment in CSC beyond the economic considerations of transaction costs. This study's findings show how neo-institutional considerations impact the finance, governance, insurance, and contractual aspects of CSC risks and transaction costs. The study sheds light on the cross-functional and multidisciplinary implications of neo-institutionalism on identifying, analyzing, and treating internal CSC (transaction cost) and external (institutional) risks and SCRM strategies. Consequently, the study provides insights into how government-sanctioned institutions could interact with state and private supply chains and further underpins the need to understand institutional mechanisms' impact on contractual and procedural coordination.

\subsection{Managerial and Theoretical Contributions}

In line with Corley and Gioia's (2011) 2X2 matrix of originality (radical and incremental) and utility (practical and theoretical), this study makes the following incremental theoretical and practical contributions. In terms of theory, by drawing on the neo-institutional and transaction cost theory, the study outlines the different neo-institutional mechanisms that underpin SCRM. This 
finding underpins Peng's (2003) argument that institutional transitions in emerging economies proceed in two phases. The findings showed that despite the introduction of new rules-based policies for SCRM, traditional relational and embedded networks shape CSC's institutional environment via distinct but interlinked neo-institutional pressures for risk analysis, identification, and treatment in state and private CSC. More so, the study advances a theoretical framework for the different neo-institutional cycles of SCRM that give rise to institutional dysmorphia between state-owned and private firms, as described by Monticelli et al. (2018).

In terms of managerial impact, the study's findings highlight the critical role of personalized networks in disseminating SCRM practices for companies engaged in Sino-foreign contracts with China. Despite some policy advances, rule-based engagements remain primarily formative, especially for local contractors and Sino-foreign projects domiciled in China. Furthermore, the study highlights how government-owned firms expand in influence through personalized networks and alliances based on relational trust. Classical theories on market-led competition argue that the deployment of rule-based legal, financial, and trade policies diminishes transaction cost risks and enables growth.

However, the existing regulatory frameworks for assessing CSC risks in China are not robust enough to account for personalized networks' influence on construction transactions. Consequently, there are conflicting pressures from institutionalized network-based SCRM and new rules-based structures in such transition economies, creating dysmorphic neo-institutional cycles that serve as transaction cost risk buffers for local CSC. The study further demonstrates that SCRM in transitioning economies operate on a spectrum of institutional regimes from relational to rule-based, depending on whether the lead firms in the chain or other significant parties are government-backed or certified as legitimate by localized networks. 
In sum, considering China's CSC's growth trajectory and the blurring of regional and national divides by globalized supply networks, this study provides useful incremental insights for construction practitioners on the neo-institutional regimes that constrain SCRM in CSC.

\subsection{Limitations and Scope for Future Studies}

Despite this study's indicative findings, there is scope to expand the study's theoretical impact in the following ways. First, while the study considers construction supply chains in China, it is acknowledged that to fully understand the institutional dynamics that drive SCRM, a broader sample that includes Sino-Foreign partners domiciled in the West would provide useful insights. Secondly, future studies could explore how cycles of neo-institutional pressures are shaped by the dynamics of public-public partnerships, which are predominant in CSC. Finally, it is essential to extend the constrained efficiency view of SCRM proposed in this study to other industries. In this regard, a cross-industry study of developed and transitioning economies would provide useful comparative analyses to advance SCRM theory building.

\section{REFERENCES}

Adhitya, A., Srinivasan, R., \& Karimi, I. A. (2009), "Supply chain risk identification using a HAZOP-based approach”, AIChE journal, Vol. 55 No. 6, pp.1447-1463.

Agrawal, V., \& Seshadri, S. (2000), "Risk intermediation in supply chains", IIE Transactions, Vol. 32 No. 9, pp.819-831.

Aloini, D., Dulmin, R., Mininno, V. and Ponticelli, S. (2012), "Supply chain management: a review of implementation risks in the construction industry", Business Process Management Journal, Vol. 18 No. 5, pp. 735-761. 
Aqlan, F. \& Lam, S.S. (2015), “Supply chain risk modelling and mitigation”, International Journal of Production Research, Vol. 53 No. 18, pp. 5640-5656.

Arantes, A., Ferreira, L. M. D., \& Costa, A. A. (2015), "Is the construction industry aware of supply chain management? The Portuguese contractors' perspective", Supply chain management: an international journal, Vol. 20 No. 4, pp. 404-414.

Barratt, M., Choi, T. Y., \& Li, M. (2011), “Qualitative case studies in operations management: Trends, research outcomes, and future research implications", Journal of Operations Management, Vol. 29 No.4, pp.329-342.

Behera, P., Mohanty, R.P. and Prakash, A. (2015), "Understanding Construction Supply Chain Management", Production Planning and Control, Vol. 26 No.16, pp.1332-1350.

Bendoly, E., Swink, M., \& Simpson III, W. P. (2014), "Prioritizing and monitoring concurrent project work: Effects on switching behaviour" Production and Operations Management, Vol. 23 No. 5, pp. 847-860.

Blome, C., \& Schoenherr, T. (2011), "Supply chain risk management in financial crises-A multiple case-study approach", International journal of production economics, Vol. 134 No. 1, pp. 43-57.

Brinkhoff, A., Özer, Ö., \& Sargut, G., (2015), “All You Need Is Trust? An Examination of Inter-organizational Supply Chain Projects", Production and operations management, Vol.24 No.2, pp.181-200.

Briscoe, G. and Dainty, A. (2005), "Construction supply chain integration: an elusive goal?" Supply Chain Management: An International Journal, Vol. 10 No. 4, pp. 319-326.

Brown, T. L., \& Potoski, M. (2003), "Managing contract performance: A transaction costs approach”, Journal of Policy analysis and Management, Vol. 22 No.2, pp. 275-297. 
Buzacott, J.A. \& Peng, H.S. (2012), "Contract design for risk sharing partnerships in manufacturing”, European Journal of Operational Research, Vol. 218 No. 3, pp. 656-666.

Chan, E. H., \& Suen, H. C. (2005), "Disputes and dispute resolution systems in Sino-foreign joint venture construction projects in China", Journal of Professional Issues in Engineering Education and Practice, Vol. 131 No.2, pp.141-148.

Chang, C. Y. (2014), "Principal-agent model of risk allocation in construction contracts and its critique", Journal of Construction Engineering and Management, Vol. 140 No.1, pp. 04013032.

Chen, C. and Orr, R.J., (2009), "Chinese contractors in Africa: Home government support, coordination mechanisms, and market entry strategies", Journal of Construction Engineering and Management, Vol. 135 No.11, pp.1201-1210.

Cheng, J. H., \& Chen, M. C. (2016), "Influence of institutional and moral orientations on relational risk management in supply chains", Journal of Purchasing and Supply Management, Vol. 22 No.2, pp.110-119.

Chileshe, N., Hosseini, M.R. and Jepson, J., (2016), "Critical Barriers to Implementing Risk Assessment and Management Practices (RAMP) in the Iranian Construction Sector", Journal of Construction in Developing Countries, Vol. 21 No.2, pp.81-112.

Choi, T. Y., \& Wu, Z. (2009), "Triads in supply networks: theorizing buyer-supplier-supplier relationships", Journal of Supply Chain Management, Vol.45 No.1, pp.8-25.

Chopra, S., \& Sodhi, M. S. (2004), "Supply-chain breakdown”, MIT Sloan management review, Vol. 46 No.1, pp.53-61. 
Chowdhury, M. M. H., \& Quaddus, M. (2016), "Supply chain readiness, response and recovery for resilience”, Supply Chain Management: An International Journal, Vol. 21 No. 6, pp. 709-731.

Colicchia, C., \& Strozzi, F. (2012), "Supply chain risk management: a new methodology for a systematic literature review", Supply Chain Management: An International Journal, Vol 17 No. 4, pp. 403-418.

Corley, K. and Gioia, D. (2011), "Building Theory about Theory Building: What Constitutes a Theoretical Contribution?" Academy of Management Review, Vol. 36 No.1, pp.12-32.

De Oliveira, U.R., Marins, F.A.S., Rocha, H.M. and Salomon, V.A.P. (2017), "The ISO 31000 standard in supply chain risk management”, Journal of Cleaner Production, Vol.151, pp. 616-633.

DiMaggio, P. J., \& Powell, W. W. (1983), "The iron cage revisited: Institutional isomorphism and collective rationality in organizational fields", American sociological review, Vol. 48 No 2, pp147-160.

Doran, D., \& Giannakis, M. (2011), “An examination of a modular supply chain: a construction sector perspective", Supply Chain Management: An International Journal, Vol. 16 No. 4, pp. $260-270$.

Emery, G. W., \& Marques, M. A. (2011), “The effect of transaction costs, payment terms and power on the level of raw materials inventories", Journal of Operations Management, Vol.29 No. 3, pp.236-249.

Fan, Y., \& Stevenson, M. (2018), “A review of supply chain risk management: definition, theory, and research agenda", International Journal of Physical Distribution \& Logistics Management, Vol. 48 No.3, pp.205-230. 
Farris, T. and Manuj, I., (2018), "Innovative Distribution Company: A Total Cost Approach to Understanding Supply Chain Risk", Council of Supply Chain Management Professionals Cases, pp.1-9.

Fearne, A. and Fowler, N. (2006), "Efficiency versus effectiveness in construction supply chains: the dangers of "lean" thinking in isolation", Supply chain management: An international journal, Vol. 11 No.4, pp.283-287.

Fischl, M., Scherrer-Rathje, M., \& Friedli, T. (2014), "Digging deeper into supply risk: a systematic literature review on price risks", Supply Chain Management: An International Journal, Vol. 19 No. 5/6, pp. 480-503.

Flanagan, R., \& Norman, G. (1993), "Risk management and construction",. Victoria, Australia.

Gabrenya, W. K., Jr., \& Hwang, K.-K. (1996), “Chinese social interaction: Harmony and hierarchy on the good earth", In M. H. Bond (Ed.), The handbook of Chinese psychology (p. 309321). Oxford University Press.

Gadde, L.E. and Dubois, A. (2010), "Partnering in the construction industry—Problems and opportunities", Journal of Purchasing and Supply Management, Vol. 16 No.4, pp. 254263.

Gentles, S. J., Charles, C., Ploeg, J., \& McKibbon, K. A. (2015), "Sampling in qualitative research: Insights from an overview of the methods literature", The qualitative report, Vol. 20 No.11, pp.1772-1789.

Golden-Biddle, K., \& Locke, K. (2007), “Composing qualitative research”, London, Sage.

Grötsch, V. M., Blome, C., \& Schleper, M. C. (2013), “Antecedents of proactive supply chain risk management-a contingency theory perspective", International Journal of Production Research, Vol. 51 No. 10, 2842-2867. 
Gümüş, M., Ray, S., \& Gurnani, H. (2012), "Supply-side story: Risks, guarantees, competition, and information asymmetry", Management Science, Vol. 58 No. 9, pp. 1694-1714.

Hajmohammad, S. \& Vachon, S. (2016), "Mitigation, avoidance, or acceptance? Managing supplier sustainability risk”, Journal of Supply Chain Management, Vol. 52 No. 2, pp. 4865.

Halldorsson, A., Kotzab, H., Mikkola, J. H., \& Skjøtt-Larsen, T. (2007), “Complementary theories to supply chain management”, Supply chain management: An international journal, Vol. 12 No. 4, pp. 284-296.

Harner, M.M. (2010), "Barriers to effective risk management”, Seton Hall Law Review, Vol.40, pp. 1323.

Hartmann, A., \& Caerteling, J. (2010), "Subcontractor procurement in construction: the interplay of price and trust", Supply chain management: An international journal, Vol. 15 No.5, pp. 354-362.

Hastak, M., \& Shaked, A. (2000), "ICRAM-1: Model for international construction risk assessment", Journal of management in engineering, Vol.16 No.1, pp.59-69.

Hatmoko, J.U.D. and Scott, S. (2006)," Simulating the Impact of Supply Chain Management Practice on Construction Project Performance", Association of Researchers in Construction Management, ARCOM, 447-457.

Hoffmann, P., Schiele, H., \& Krabbendam, K. (2013), "Uncertainty, supply risk management and their impact on performance", Journal of purchasing and supply management, Vol.19 No. 3, pp.199-211. 
Humphreys, P., Matthews, J., \& Kumaraswamy, M. (2003), "Pre-construction project partnering: from adversarial to collaborative relationships", Supply Chain Management: An International Journal, Vol. 8 No. 2, pp. 166-178.

Hurley, J., Morris, S., \& Portelance, G. (2019), "Examining the debt implications of the Belt and Road Initiative from a policy perspective", Journal of Infrastructure, Policy and Development, Vol.3 No.1, pp.139-175.

Hwang, K. K. (1987), "Face and favor: The Chinese power game”, American journal of Sociology, Vol. 92 No. 4, pp. 944-974.

ISO, (2009), "International Organization for Standardization (ISO) Risk Management - Principles and Guidelines (2009), ISO 31000:2009, IDT

Kache, F., \& Seuring, S. (2014), "Linking collaboration and integration to risk and performance in supply chains via a review of literature reviews", Supply Chain Management: An International Journal, Vol. 19 No. 5/6, pp. 664-682.

Kleindorfer, P.R., and Saad, G.H. (2005), "Managing disruption risks in supply chains", Production and Operations Management, Vol. 14 No.1, pp.53-68.

Kurniawan, R., Zailani, S. H., Iranmanesh, M., \& Rajagopal, P. (2017), "The effects of vulnerability mitigation strategies on supply chain effectiveness: risk culture as moderator" Supply Chain Management: An International Journal, Vol. 22 No. 1, pp.1-15.

Kwon, S. W., Lee, I. W., \& Feiock, R. C. (2010), "Transaction Cost Politics and Local Service Production", International Review of Public Administration, Vol.14 No. 3, pp.37-52.

Langley, A. (1999), "Strategies for theorizing from process data", Academy of Management review, Vol.24 No.4, pp.691-710. 
Lavikka, R. H., Smeds, R., \& Jaatinen, M. (2015). “Coordinating collaboration in contractually different complex construction projects", Supply chain management: an international journal. Vol. 20 No. 2, pp. 205-217.

Liu, H., Ke, W., Wei, K.K., Gu, J. and Chen, H., (2010), “The role of institutional pressures and organizational culture in the firm's intention to adopt internet-enabled supply chain management systems", Journal of Operations Management, Vol. 28 No.5, pp.372-384.

Lönngren, H. M., Rosenkranz, C., \& Kolbe, H. (2010), “Aggregated construction supply chains: success factors in implementation of strategic partnerships", Supply Chain Management: An International Journal, Vol. 15 No. 5, pp. 404-411.

Lu, P., Guo, S., Qian, L., He, P., \& Xu, X. (2015), “The effectiveness of contractual and relational governances in construction projects in China", International Journal of Project Management, Vol. 33 No.1, pp. 212-222.

Manuj, I. and Mentzer, J.T. (2008), "Global supply chain risk management strategies", International Journal of Physical Distribution \& Logistics Management. Vol. 38 No. 3, pp. 192-223.

McCloskey, D. N. (2016), "The humanities are scientific: a reply to the defences of economic neoinstitutionalism”, Journal of Institutional Economics, Vol. 12 No.1, pp. 63-78.

Mohr, L. B. (1982), “Explaining organizational behavior”, San Francisco, Jossey-Bass.

Monticelli, J.M., Garrido, I.L., Curth, M., Vieira, L.M. and Dal-Soto, F. (2018), "Institutional dysmorphia: when the institutions become ill", International Journal of Emerging Markets, Vol. 13 No. 3, pp. 478-498.

Morck, R., Yeung, B., \& Zhao, M. (2008), "Perspectives on China's outward foreign direct investment", Journal of International Business Studies, Vol. 39 No. 3, pp. 337-350. 
Morse, J. M. (1994), "Emerging from the data: The cognitive processes of analysis in qualitative inquiry", in J. M. Morse (Ed.) Critical issues in qualitative research methods, pp. 23-43, London, Sage.

Oliver, C. (1992), “The antecedents of deinstitutionalization”, Organization studies, Vol. 13 No.4, pp. 563-588.

Olson, D. L., \& Wu, D. (2011), "Risk management models for supply chain: a scenario analysis of outsourcing to China”, Supply Chain Management: An International Journal, Vol.16 No.6, pp. 401-408.

Osipova, E. (2015). Establishing cooperative relationships and joint risk management in construction projects: Agency theory perspective. Journal of management in engineering, Vol.31 No.6.

Park, K., Min, H. \& Min, S. (2016), “Inter-relationship among risk taking propensity, supply chain security practices, and supply chain disruption occurrence”, Journal of Purchasing and Supply Management, Vol. 22 No. 2, pp. 120-130.

Park, S. H., \& Luo, Y. (2001), “Guanxi and organizational dynamics: Organizational networking in Chinese firms", Strategic management journal, Vol. 22 No.5, pp. 455-477.

Peel, M., \& Mitchell, T. (2017), “Asia’s \$26tn infrastructure gap threatens growth, ADB warns”, Financial Times. Available at: https://www.ft.com/content/79d9e36e-fd0b-11e6-8d8ea5e3738f9ae4 [Accessed 5 April 2020].

Peng, M. W. (2002), "Towards an institution-based view of business strategy", Asia Pacific Journal of Management, Vo. 19 No. 2-3, pp. 251-268.

Peng, M. W. (2003), "Institutional transitions and strategic choices", Academy of Management Review, Vol. 28 No. 2, pp. 275-296. 
Peng, M. W. (2004), “Outside directors and firm performance during institutional transitions", Strategic management journal, Vol. 25 No.5, pp.453-471.

Peng, M. W., \& Heath, P. (1996), "The growth of the firm in planned economies in transition: institutions, organizations, and strategic choice", The Academy of Management Review, Vol. 21 No. 2, pp. 492-528.

Peng, M. W., \& Luo, Y. (2000). Managerial ties and firm performance in a transition economy: The nature of a micro-macro link. Academy of management journal, 43(3), 486-501.

Raz, T. and Michael, E. (2001), "Use and benefits of tools for project risk management", International Journal of Project Management, Vol. 19 No. 1, pp. 9-17.

Riley, J. M., Klein, R., Miller, J., \& Sridharan, V. (2016), "How internal integration, information sharing, and training affect supply chain risk management capabilities", International Journal of Physical Distribution \& Logistics Management, Vol. 46 No.10, pp.953-980.

Ritchie, B., \& Brindley, C. (2007), "Supply chain risk management and performance: a guiding framework for future development", International Journal of Operations \& Production Management, Vol. 27 No. 3, pp.303-322.

Roberts, P. W., \& Greenwood, R. (1997), “Integrating transaction cost and institutional theories: Toward a constrained-efficiency framework for understanding organizational design adoption", Academy of management review, Vol. 22 No. 2, pp. 346-373.

Rudolf, C. A., \& Spinler, S. (2018), "Key risks in the supply chain of large scale engineering and construction projects", Supply Chain Management: An International Journal, Vol. 23 No. 4, pp. 336-350.

Segerstedt, A., \& Olofsson, T., (2010), "Supply chains in the construction industry”, Supply Chain Management: An International Journal, Vol. 15 No. 5, pp. 347-353. 
Shen, L. Y., Platten, A. and Deng, X. P., (2006), "Role of public private partnerships to manage risks in public sector projects in Hong Kong", International Journal of Project Management 2, Vol. 24 No. 7, pp. 587-594.

Sousa, V., De Almeida, N. M., \& Dias, L. A. (2012), "Risk management framework for the construction industry according to the ISO 31000: 2009 standard", Journal of Risk Analysis and Crisis Response, Vol. 2 No 4, pp. 261-274.

Spiggle, S. (1994), "Analysis and interpretation of qualitative data in consumer research", Journal of consumer research, Vol. 21 No.3, pp. 491-503.

Stranieri, S., Orsi, L., \& Banterle, A. (2017), “Traceability and risks: an extended transaction cost perspective", Supply Chain Management: An International Journal, Vol. 22 No. 2, pp. 145-159.

Strauss, A., \& Corbin, J. (1998), “Basics of qualitative research techniques”, Thousand Oaks, CA: Sage publications.

Suddaby, R., (2015), “Can institutional theory be critical?”, Journal of Management Inquiry, Vol. 24 No. 1, pp. 93-95.

Tsang, E. W. (1998), "Can guanxi be a source of sustained competitive advantage for doing business in China?", Academy of Management Perspectives, Vo. 12 No.2, pp.64-73.

Tummala, R. \& Schoenherr, T. (2011), “Assessing and managing risks using the supply chain risk management process (SCRMP)", Supply Chain Management: An International Journal, Vol. 16 No. 6, pp. 474-483.

Van de Ven, A. H., \& Huber, G. P. (1990), "Longitudinal field research methods for studying processes of organizational change2, Organization science, Vol. 1 No. 3, pp. 213-219. 
Van de Ven, A. H., \& Poole, M. S. (2005), “Alternative approaches for studying organizational change", Organization studies, Vol. 26 No. 9, pp.1377-1404.

Van de Ven, A. H., Ganco, M., \& Hinings, C. R. (2013), "Returning to the frontier of contingency theory of organizational and institutional designs", The Academy of Management Annals, Vol. 7 No.1, pp.393-440.

Wang, D., Li, K. and Fang, S., (2018), “Analyzing the factors influencing trust in a construction project: evidence from a Sino-German eco-park in China”, Journal of Civil Engineering and Management, 24(4), pp.331-343.

Wang, Y., Gilland, W., \& Tomlin, B. (2011), "Regulatory trade risk and supply chain strategy", Production and Operations Management, No. 20 No. 4, pp. 522-540.

Wever, M., Wognum, P. M., Trienekens, J. H., \& Omta, S. W. F. (2012), "Supply chain-wide consequences of transaction risks and their contractual solutions: Towards an extended transaction cost economics framework", Journal of Supply Chain Management, Vol. 48 No.1, pp.73-91.

Williamson, O. E. (1987). "Transaction cost economics: The comparative contracting perspective", Journal of economic behavior \& organization, Vol. 8 No.4, pp. 617-625.

Williamson, O. E. (1990), “A comparison of alternative approaches to economic organization”, Journal of Institutional and Theoretical Economics (JITE)/Zeitschrift für die gesamte Staatswissenschaft, pp. 61-71.

Wu, Y., Ramachandran, K., \& Krishnan, V. (2014), "Managing cost salience and procrastination in projects: Compensation and team composition", Production and Operations Management, Vol. 23 No. 8, pp. 1299-1311. 
Wynstra, F., Spring, M., \& Schoenherr, T. (2015), “Service triads: A research agenda for buyersupplier-customer triads in business services", Journal of Operations Management, Vol.35, pp.1-20.

Yow Thim, L. A. M., \& Zonggui, C. (2004), “The development of the construction legal system in China", Construction Management and Economics, Vol. 22 No.4, pp.347-356.

Zipkin, P. (2012), “A reply to Williamson's “outsourcing...”,, Production and Operations Management, Vol. 21 No. 3, pp. 465-469.

Zsidisin, G.A. and Ellram, L.M., (2003), “An agency theory investigation of supply risk management”, Journal of supply chain management, Vol.39 No. 2, pp.15-27.

Zsidisin, G.A., Melnyk, S.A. and Ragatz, G.L., (2005) “An institutional theory perspective of business continuity planning for purchasing and supply management”, International journal of production research, Vol. 43 No.16, pp.3401-3420.

Zuckerman, E. W. (1999), "The categorical imperative: Securities analysts and the illegitimacy discount", American journal of sociology, Vol. 104 No. 5, pp. 1398-1438.

\section{Appendix 1a Interview Questions}

Question 1: How would you define supply chain risk in the construction industry?

Question 2: What are the main categories of supply chain risks that affect the company's operations and projects?

Question 3: What are your views on the role of supply chain risk management (SCRM) in the construction industry?

Question 4: From your experience, what are the primary cost implications of implementing/or not implementing SCRM practices with your partners?

Question 5: From the risk management techniques listed below, please indicate the ones you are familiar with and those you have used before in your firm. Please give some examples and explain why.

\begin{tabular}{|l|l|l|}
\hline Techniques/tools & Familiar with & Used before \\
\hline Assumption & & \\
\hline Brainstorming & & \\
\hline Interviews & & \\
\hline Checklists & & \\
\hline The Delphi Technique & & \\
\hline
\end{tabular}




\begin{tabular}{|l|l|l|}
\hline Risk Register & & \\
\hline Failure Mode and Effects Analysis (FMEA) & & \\
\hline Decision Tree & & \\
\hline Sensitivity Analysis & & \\
\hline Monte Carlo Simulation & & \\
\hline Possibility Analysis & & \\
\hline probability distribution & & \\
\hline data gathering and representation techniques & & \\
\hline expected monetary value analysis & & \\
\hline tornado diagrams & & \\
\hline Others specify & & \\
\hline
\end{tabular}

Question 6: Do you prefer qualitative or quantitative techniques? Please give reasons.

Question 7: How is SCRM viewed in your firm, proactively or reactively? Please give some reasons.

Question 8: From the risk treatment strategies listed below, please indicate which ones you are familiar with and those you have used before. Please explain with examples.

\begin{tabular}{|l|l|l|}
\hline Risk treatment methods & Familiar with & Experienced \\
\hline Risk Avoidance & & \\
\hline Risk Reduction & & \\
\hline Risk Transfer & & \\
\hline Risk Retention & & \\
\hline
\end{tabular}

Question 9: Based on your experience, what are the primary cost drivers or barriers to implementing SCRM in the construction industry from pre to post contract project operations? (e.g., search, screening, bargaining, transfer, monitoring and enforcement costs).

Question 10: Based on your experience, what are the primary institutional drivers or barriers to implementing SCRM in the construction industry from pre to post contract project operations? (Regulations, norms, other players)

\section{Appendix 1b Sample of Transcript Reference}

Mandarin Quotes from Respondent A

“我们必须通过更新和评估支持在线交流和信息共享所需的不同工具和IT平台，加强与供应商和分包商的合 作关系, 我们的IT能力允许我们识别和管理潜在的建设项目风险; 否则, 如果我们不具备与合作伙伴进行 IT互操作性的能力, 就很容易失去对项目的控制。”

“中国负责公共采购的主要政府机构是财政部。国家发展和改革委员会、科技部、商务部、交通部、住房和 城乡建设部等其他部委对建设项目的进行了不同方面的规范和监督。地方政府当局应该监督和管理地方政 府的采购和建设活动, 然而, 这些不同的机构可能会向承包商传达相互冲突的信息, 因此, 我们必须习惯 于了解每个项目的突然政策变化。”

“我们有时需要花费大量的时间和资源来计算我们的议价成本, 大多数涉及政府客户的项目中, 议价成本对 最终报价的合同价格有重大影响, 如果我们不能正确地评估议价成本, 而误引了合同价, 那对我们来说成 本就会很高。”

“我们的许多外国分包商认为我们的国家资格体系偏祖本地承包商是具有歧视性的。他们主要批评的是招标 要求, 要求所有资格证明只能从中国获得。此外, 与我们合作的许多外国外包商不熟悉中国的法律制度, 因此，与其他国家相比，这不仅会延长签约过程，而且会产生不可预测的转让和监控成本。” 
“建筑设计专业人员的许可程序相当繁琐, 由于只有在中国获得许可的公司才能正式批准建设计划, 这就增 加了与全球合作伙伴参与联合项目的监控成本。” 
Table 1: Transaction Costs in CSC

\begin{tabular}{|c|c|c|}
\hline $\begin{array}{l}\text { Transaction } \\
\text { costs drivers of } \\
\text { SCRM }\end{array}$ & Source/origin of costs & $\begin{array}{l}\text { Tangible } \\
\text { transaction cost } \\
\text { drivers }\end{array}$ \\
\hline $\begin{array}{l}\text { Search/Switching } \\
\text { costs }\end{array}$ & $\begin{array}{l}\text { Result from poor knowledge of risk profiles, } \\
\text { demand and supply dynamics, trading rights, or } \\
\text { market opportunities. } \\
\text { Search costs are predominantly tied to knowledge } \\
\text { appropriability regimes and other tangible resource } \\
\text { constraints }\end{array}$ & $\begin{array}{l}\text { Personal/ expertise } \\
\text { cost and time. } \\
\text { Travel expenses. } \\
\text { Communication } \\
\text { and negotiation } \\
\text { costs. }\end{array}$ \\
\hline Screening costs & $\begin{array}{l}\text { Result from uncertainties about potential } \\
\text { suppliers/buyers quality and reliability or about the } \\
\text { reliability. Screening costs are predominantly tied to } \\
\text { the prevalent industry dynamics, business focus, } \\
\text { resource constraints and location-specific qualities of } \\
\text { firms }\end{array}$ & $\begin{array}{l}\text { Consulting service } \\
\text { fees } \\
\text { Legal search costs. }\end{array}$ \\
\hline Bargaining costs & $\begin{array}{l}\text { Result from conflicting objectives among transacting } \\
\text { parties and unclear contracting terms, rights, and } \\
\text { obligations. } \\
\text { Bargaining costs are predominantly tied to the power } \\
\text { dynamics and information asymmetries among } \\
\text { industry players }\end{array}$ & $\begin{array}{l}\text { Costs of credit } \\
\text { rating checks } \\
\text { Licensing fees } \\
\text { Insurance } \\
\text { premiums }\end{array}$ \\
\hline Transfer costs & $\begin{array}{l}\text { Result from legal, extra-legal and physical limits } \\
\text { to goods and service movement. } \\
\text { Transfer costs are predominantly tied to the national } \\
\text { and supranational compliance structures }\end{array}$ & $\begin{array}{l}\text { Handling/storage } \\
\text { costs } \\
\text { transport costs } \\
\text { bribery and } \\
\text { corruption } \\
\text { expenses }\end{array}$ \\
\hline Monitoring costs & $\begin{array}{l}\text { Poor transactor compliance maturity, fluid } \\
\text { operational and service-level measurement } \\
\text { parameters. } \\
\text { Monitoring costs are predominantly tied to the socio- } \\
\text { cultural and socio-political structures of firms }\end{array}$ & $\begin{array}{l}\text { Auditing fees } \\
\text { product inspection } \\
\text { charges } \\
\text { Investments in } \\
\text { measurement } \\
\text { devices }\end{array}$ \\
\hline $\begin{array}{l}\text { Enforcement } \\
\text { costs }\end{array}$ & $\begin{array}{l}\text { Result from uncertainty about contractual remedies } \\
\text { for non-compliance and bilateral or third party } \\
\text { jurisdiction induced penalties. } \\
\text { Enforcement costs are predominantly tied to the } \\
\text { national and supranational compliance structures } \\
\text { surrounding a firm }\end{array}$ & $\begin{array}{l}\text { Arbitration, legal, } \\
\text { court fees, financial } \\
\text { and relational costs } \\
\text { of social pressure. }\end{array}$ \\
\hline
\end{tabular}


Table 2: Summary of Review Constructs

\begin{tabular}{|c|c|c|c|}
\hline CSC risk Categories & $\begin{array}{l}\text { SCRM Transaction costs in } \\
\text { CSC }\end{array}$ & $\begin{array}{l}\text { Neo-Institutional drivers of } \\
\text { isomorphism or } \\
\text { Dysmorphia in CSC }\end{array}$ & $\begin{array}{l}\text { SCRM risk treatment } \\
\text { approaches in CSC }\end{array}$ \\
\hline $\begin{array}{l}\text { - } \text { Financial risks } \\
\text { - Legal risks } \\
\text { - Management risks } \\
\text { - Market risks } \\
\text { - Policy risk } \\
\text { - Technical risks. } \\
\text { (Colicchia and Strozzi, } \\
\text { 2012Fearne and Fowler, } \\
\text { 2006) }\end{array}$ & $\begin{array}{l}\text { - } \quad \text { Search costs } \\
\text { - } \quad \text { Screening costs } \\
\text { - } \quad \text { Bargaining costs } \\
\text { - } \quad \text { Transfer costs } \\
\text { - } \quad \text { Monitoring costs } \\
\text { - } \quad \text { Enforcement costs } \\
\text { (Emery and Marques, 2011; } \\
\text { Stranieri et al., 2017; Zipkin, } \\
\text { 2012) }\end{array}$ & $\begin{array}{l}\text { - } \quad \text { Regulatory drivers } \\
\text { - } \quad \text { Normative drivers } \\
\text { - } \quad \text { Mimetic drivers } \\
\text { ( Peng, 2003; Suddaby, 2015; } \\
\text { Williamson, 1990) }\end{array}$ & $\begin{array}{l}\text { - } \quad \text { Risk avoidance } \\
\text { - Risk reduction } \\
\text { - } \quad \text { Risk transfer } \\
\text { - } \quad \text { Risk retention } \\
\text { (Aqlan and Lam, 2015; } \\
\text { Hajmohammad and } \\
\text { Vachon, 2016). }\end{array}$ \\
\hline
\end{tabular}

Table 3: Company and Corresponding Interview Respondents Codes

\begin{tabular}{|c|c|c|}
\hline Case Organizations & $\begin{array}{l}\text { Respondent } \\
\text { Code }\end{array}$ & Position \\
\hline \multirow{3}{*}{$\begin{array}{l}\text { Case A } \\
\text { Large state-owned } \\
\text { construction firm }\end{array}$} & A & Supply Chain Director \\
\hline & $\mathrm{B}$ & Project Coordinator \\
\hline & $\mathrm{C}$ & Procurement Manager \\
\hline \multirow{3}{*}{$\begin{array}{l}\text { Case B } \\
\text { Medium-scale Privately } \\
\text { owned construction firm }\end{array}$} & $\mathrm{D}$ & $\begin{array}{l}\text { Engineering, Procurement, and Construction } \\
\text { Director }\end{array}$ \\
\hline & E & Project manager \\
\hline & $\mathrm{F}$ & Purchasing Specialist \\
\hline \multirow{3}{*}{$\begin{array}{l}\text { Case C } \\
\text { China-Based Construction } \\
\text { consortium with EPC and } \\
\text { EPCF operations in China } \\
\text { and overseas }\end{array}$} & $\mathrm{G}$ & $\begin{array}{l}\text { Supply Chain Manager for an electrical } \\
\text { installation EPC contractor }\end{array}$ \\
\hline & $\mathrm{H}$ & $\begin{array}{l}\text { Director for Purchasing and Supply Chain } \\
\text { Planning for a building material supplier }\end{array}$ \\
\hline & $\mathrm{I}$ & $\begin{array}{l}\text { Project manager (EPC) for a construction } \\
\text { equipment supplier }\end{array}$ \\
\hline \multicolumn{3}{|c|}{$\begin{array}{l}\text { Case polarity considerations for Case A and B: } \\
\text { 1. Public versus private ownership } \\
\text { 2. Predominant lead contractor versus predominant sub-contractor } \\
\text { 3. Large-scale by size of project portfolio and international reach versus medium scale }\end{array}$} \\
\hline
\end{tabular}




\section{Descriptive Codes}

"Ministerial authorities regulate and oversee different aspects of construction work" "We have a bespoke system with several ministerial authorities"

"Government selects contractors for risky phases using private tenders or tenders by invitation".

"Predominant target cost contracts (TCC) as a form of risk-sharing with pre-set incentives to ensure efficient performance"

"Minimize the shifting of risks to contractor by rewarding sub-contractor performance"

"A certain level of socialized connections within the industry and the system is required to develop intellectual property, possess a registered trademark or have the right licenses to use certain intellectual property in China"

"There is an institutionalized perception of a lowcost advantage in the industry here".

"Firms licensed in China can officially validate construction plans".
Phrasal Codes

Command and control pressure to adapt the SCRM principles and protocols of stateowned firms and regulators

Pressure to devise efficient SCRM strategies to meet regulatory standards
Analytical Codes

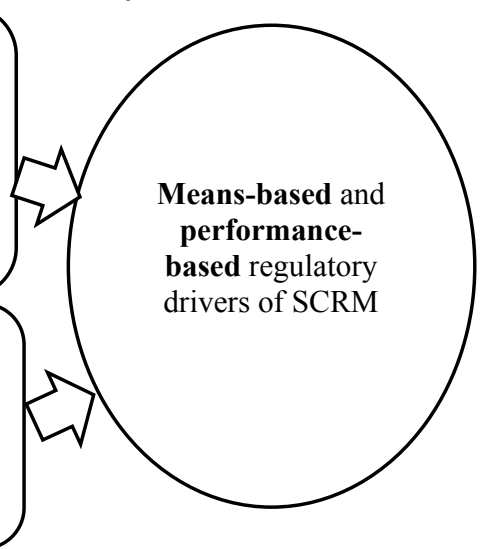

"You have to adapt because avoiding risks even after a client's risk profile is assessed as poor can cost us future projects and prospective business opportunities."
Pressure from the actual prevalence of a

SCRM normative behaviour

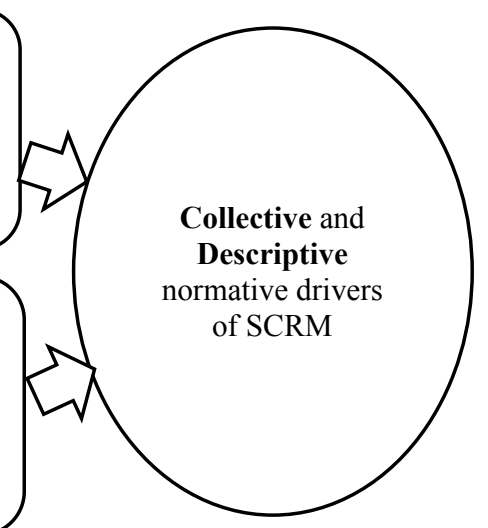

"Our main risk treatment approach is mainly dictated by our lead state-owned contractors and regulators".

"Risk avoidance in commercial contracts with state agents can be a long running added expense

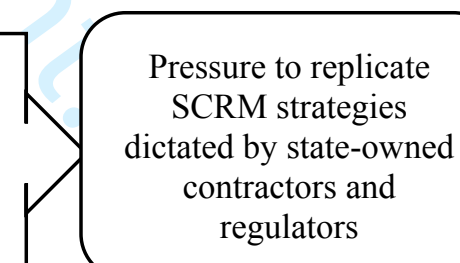

Pressure from the perceived prevalence of a normative SCRM behaviour

Pressure to adapt SCRM in line with relational cues from lead contractors.

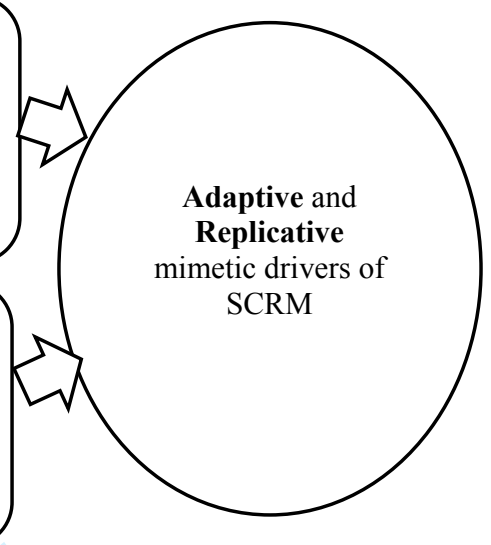




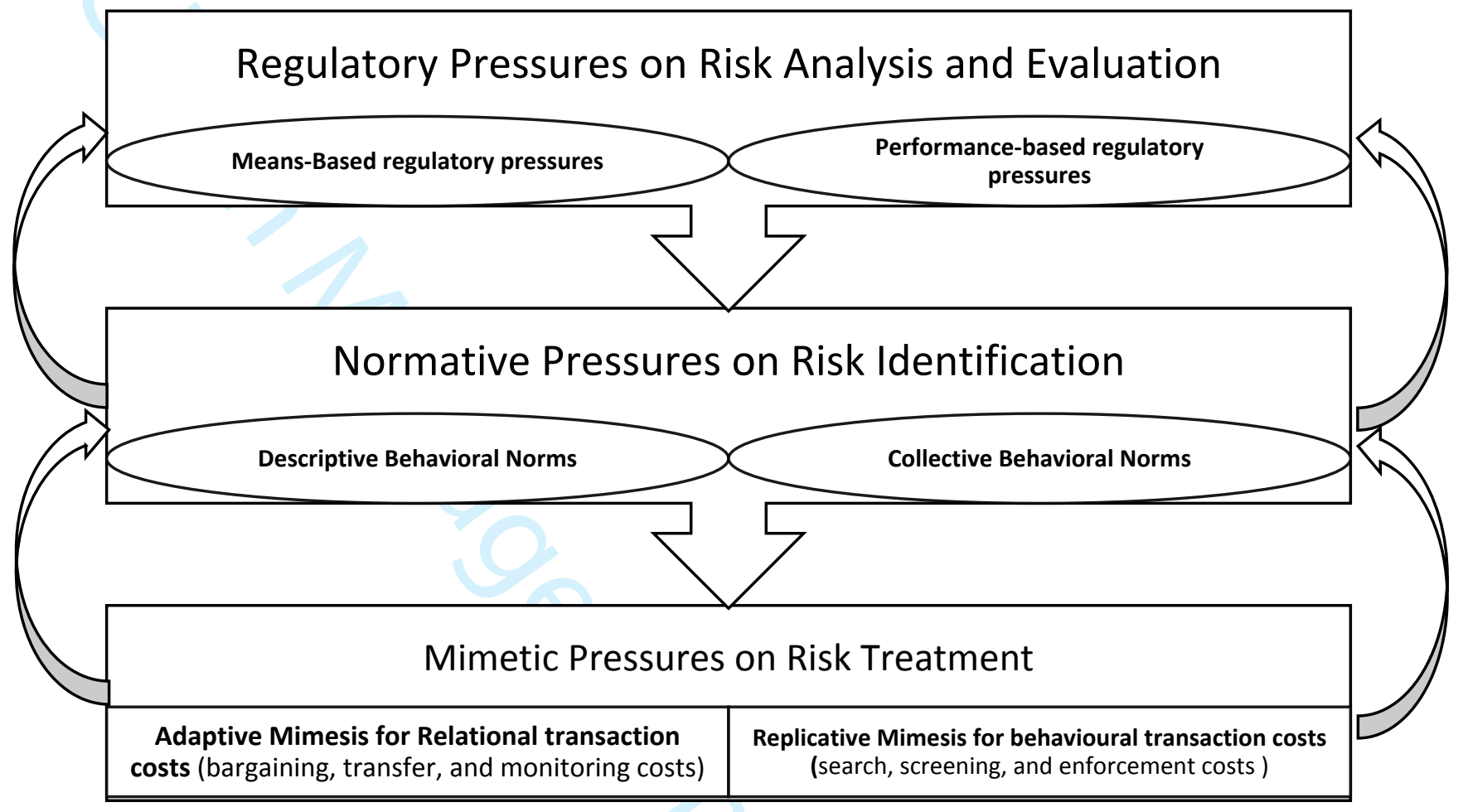

Figure 2: Neo-Institutional Dynamics of SCRM in CSC 